\title{
The Countries AND TRIBES OF THE PERSIAN GULF
}




\title{
The Kegan Paul Arabia library
}

\section{EDITORIAL ADVISOR PETER HOPKINS}

\author{
THE SYRIAN DESERT \\ Christina Phelps Grant \\ THE TRAGEDY OF THE ASSYRIAN \\ MINORITY IN IRAQ \\ R. S. Stafford
THE TRIBES OF THE MARSH ARABS OF IRAQ
Fulanain \\ THE VANISHED CITIES OF \\ ARABIA \\ Mrs. Steuart Erskine \\ ARABIA AND THE ISLES \\ Harold Ingrams \\ STUDIES IN ISLAMIC MYSTICISM \\ Reynold A. Nicholson
LORD OF ARABIA: IBN SAUD
H. C. Armstrong \\ AVARICE AND THE AVARICIOUS \\ Abu 'Uthman' Amr ibn Bahr al- \\ Jahiz \\ TWO ANDALUSIAN \\ PHILOSOPHERS \\ Abu Bakr Muhammad ibn Tufayl \\ \& Abu'l Walid Muhammad Ibn \\ Rushd
THE PERFUMED GARDEN OF
SENSUAL DELIGHT
Muhammad ibn Muhammad al- Nafzawi \\ THE WELLS OF IBN SAUD \\ D. van der Meulen \\ ADVENTURES IN ARABIA \\ W. B. Seabrook
A PALADIN OF ARABIA NNE Bray

\author{
POEMS OF WINE \& REVELRY \\ Jim Colville (translator)
}

THE ANTHROPOLOGY OF IRAQ Henry Field

THE MANNERS AND CUSTOMS OF THE MODERN EGYPTIANS Edward William Lane

SOUTHERN ARABIA

J. Theodore Bent

IRAQ

Philip Willard Ireland

THE SAND KINGS OF OMAN Raymond O'Shea

THE BLACK TENTS OF ARABIA Carl S. Raswan

BEDOUIN JUSTICE

Austin Kennett

THE ARAB AWAKENING

George Antonius

Arabia Phoenix

Gerald De Gaury

THE LONG ROAD TO BAGHDAD Edmund Candler
SOBRIETY AND MIRTH Jim Colville

THE COUNTRIES AND TRIBES OF THE PERSIAN GULF Col. S. B. Miles

ARABIC Culture THROUGH ITS

LANGUAGE AND LITERATURE M. H. Bakalla

IBN SA'OUD OF ARABIA Ameen Rihani

IRAQFROM MANDATE TO

INDEPENDENCE

Ernest Main 


\title{
THE \\ COUNTRIES AND TRIBES \\ OF THE \\ PERSIAN GULF
}

\author{
VOLUME II
}

\section{COL. S. B. MILES}

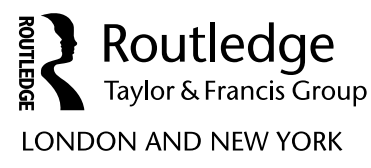




\section{First published in 2005 by}

Kegan Paul Limited

Published 2017 by Routledge

2 Park Square, Milton Park, Abingdon, Oxfordshire OXI4 4RN

Routledge is an imprint of the Taylor and Francis Group, an informa business

Distributed by:

Columbia University Press

61 West $62^{\text {nd }}$ Street, New York, NY 10023

Tel: (212) 4590600 Fax: (212) 4593678

Internet: http://www.columbia.edu/cu/cup

(C) Taylor and Francis, 2005

All Rights reserved. No part of this book may be reprinted or reproduced or utilised in any form or by any electric, mechanical or other means, now known or hereafter invented, including photocopying or recording, or in any information storage or retrieval system, without permission in writing from the publishers.

ISBN 13: 978-1-138-71299-7 (hbk)

ISBN 13: 978-1-138-71346-8 (pbk)

\section{British Library Cataloguing in Publication Data}

\section{Library of Congress Cataloging-in-Publication Data \\ Applied for.}

\section{Publisher's Note}

The publisher has gone to great lengths to ensure the quality of this reprint but points out that some imperfections in the original copies may be apparent. 


\section{Contents}

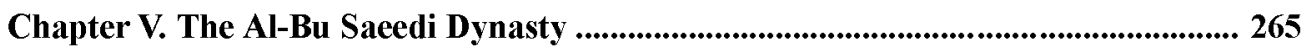

Chapter VI. History of the Commerce of the Persian Gulf .............................................. 355

Chapter VII. Description of the Country and the Pearl Fisheries ............................... 374

Chapter VIII. The Tribes of the Persian Gulf ................................................................... 418

Chapter IX. Arabia, Eastern and South Eastern, and the Kooria Mooria Islands ..... 439

Chapter X. History and Geography of Dhofar. Dhofar and Beraimi Described ......... 498

APPENDIX. A Slight Sketch of Colonel S. B. Miles' Travels in Mesopotamia from December, 1879, to April, 1880 ....................................................................................... 558

Index. 


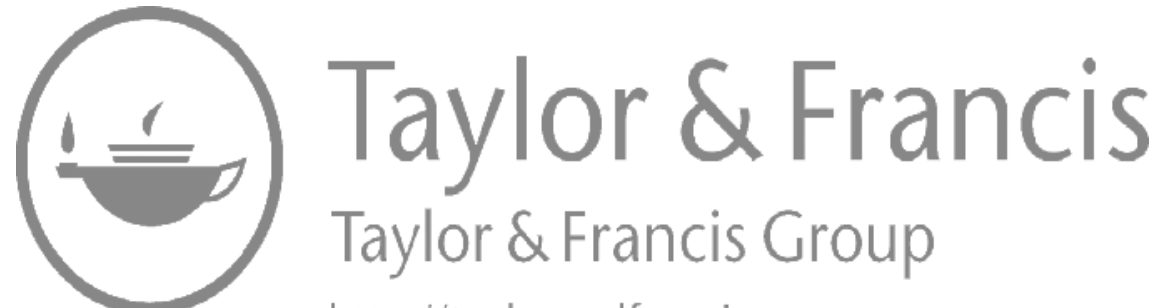
http://taylorandfrancis.com 


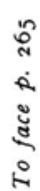

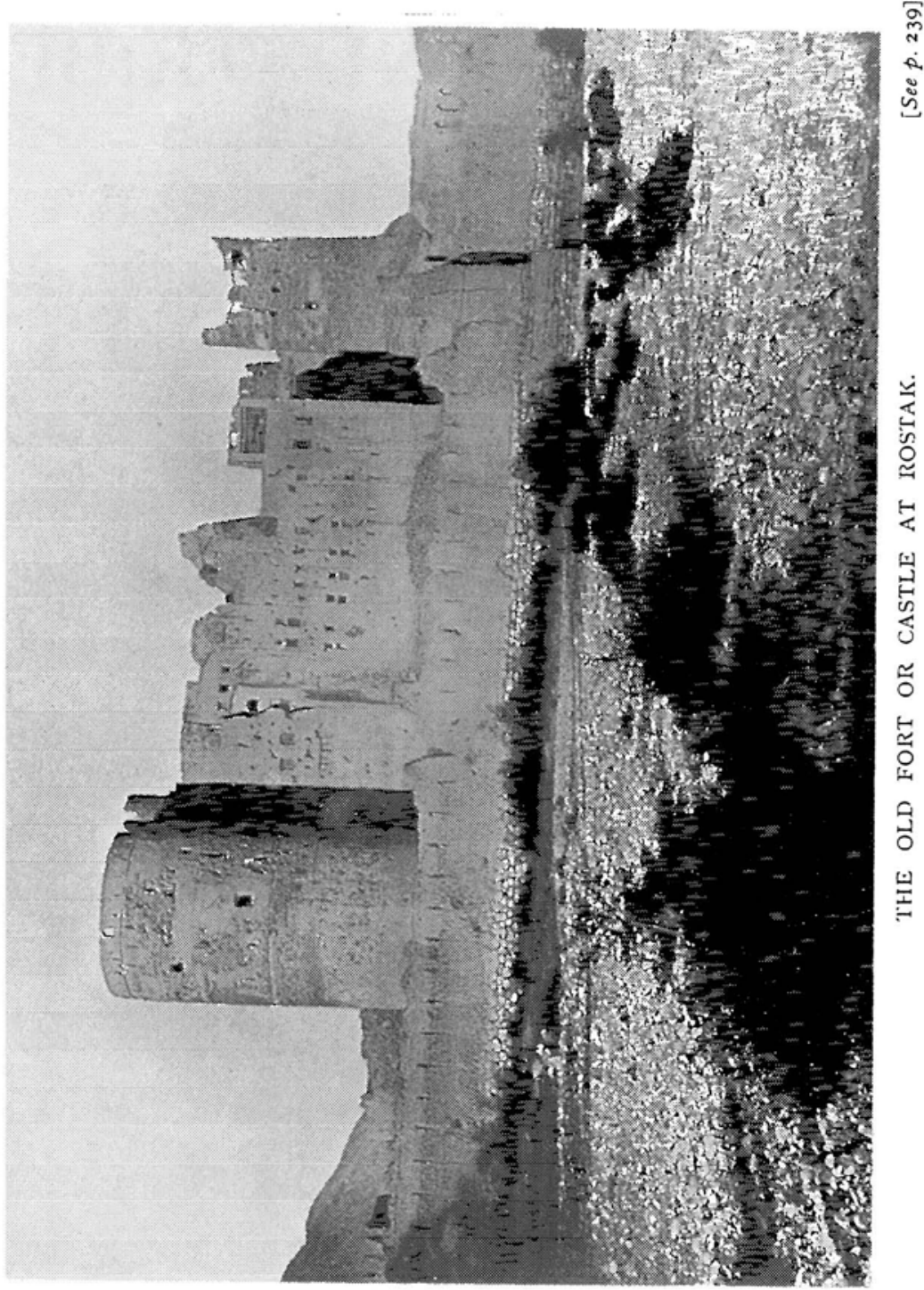

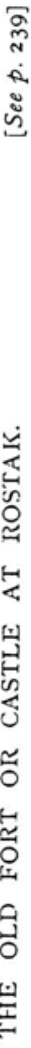




\section{CHAPTER V.}

\section{THE AL-BU SAEEDI DYNASTY.}

THE Yaareba had been the most powerful dynasty that Oman had ever seen. It had held sway for about a century and a quarter and had during that period, by the administrative ability, energy and enterprise of its princes, raised the status, power, and prosperity of the country to a greater height than it had ever previously attained. Yet its fall was rapid, humiliating, and irretrievable, and the star of those enterprising princes, who had done so much for Oman, for good and evil, had set for ever. The date of this event, viz., I749, is confirmed by Niebuhr, who tells us that in the year 1765 Ahmed bin Saeed had reigned sixteen years.

Relieved of the anxiety and perils of civil war, Ahmed was now able to turn his attention to administrative affairs, and by a quick move made himself master of Rostak, which had been for about 125 years the capital of Oman, and established his residence there, appropriating to himself all the castles-bait al mal-or crown lands, and other property.

In the main fortresses of the country, viz., Nezwa, Bahila, Zikki, and Semail, etc., he appointed men of his own selection as governors, and then with a strong hand set to work to repress many of the abuses that had crept into the State. In place of the thievish rabble soldiery maintained by his predecessors, he substituted a well-equipped and efficient body of African slaves, who are said to have been well behaved and faithful. 
In order to still further consolidate his position, Ahmed, shortly after his accession to power, formed an alliance with the dynasty he had overthrown by espousing the daughter of the late Imam Saif bin Sultan, by whom he had a son named Mohammed.

Nothing, however, served so well to confirm him in the Imamate as his firm and sagacious administration, which soon gained him the loyal support and respect of the people.

With the fall of the Yaareba Dynasty the policy of adventure, or predatory exploits, which had distinguished them during their rule, fell also, and with the rise of the Al-Bu Saeedis the reople of Oman returned under the wise guidance of Ahmed bin Saeed to the more simple and legitimate ways of commercial intercourse with other nations. The city of Muscat had rapidly recovered from the depression caused by the temporary occupation of the Persians, and became more populous and thriving than ever.

The Imam, looking round to see how he could best encourage the seaborne trade of his merchants, whose vessels at this period visited not only the ports of the Persian Gulf but those of Western India, Java, Mauritius, the Red Sea and East Africa, naturally directed his attention first to his own colonies in Africa, where it was necessary to obtain recognition of his sovereignty and make his authority felt and respected. In the ensuing north-east monsoon (I750), he accordingly despatched ships to the ports of Mombasa, Kilwa, and Zanzibar, appointing men on whom he could depend as governors. Although trade relations had no doubt existed between Oman and East Africa from immemorial times, as the slave markets of Persia and Mesopotamia could have been supplied in no other way, it was not until the first half of the seventeenth century that the Arabs began to acquire territorial possessions there. when, having been invited by the inhabitants of the country to protect them from their Portuguese oppressors, expeditions were sent from Muscat to capture and occupy Kilwa and Mombasa.

At this time the trade, though still quite undeveloped, was of considerable importance and value, consisting chiefly of slaves, ivory, copal and timber; and a large number of vessels were engaged in 
taking from Oman cargoes of dates and other articles in exchange for the commodities above mentioned.

The prosperity of Oman trade about this period was partly due to the increased security open to navigators by the disappearance of the most formidable piratical fleet then menacing commerce in the Indian Ocean, viz., that of Toolajee Angria of Gheriah, from whose depredations the Arabs and Persians had suffered very severely until it had been finally crushed by Admiral Watson. As the Angrias were of Arab extraction it may be as well to give a slight sketch of the rise of these notorious pirates, who paralyzed commerce in the Indian Seas for so many years. In the year I643, a Muscat dhow was wrecked off the Indian coast near Rajapore in the dominions of the Sahujee Raja. The captain was killed and most of the crew made captives. Among the latter was a half-caste Arab, named Sambhoo, who, being a man of uncommon courage and ability, soon distinguished himself and was able, after many adventures and exploits, to establish himself on the coast in partial independence as a pirate. He was killed in a fight with the Moghul's troops in I675, leaving a son, Poora, who successfully carried on his father's lucrative profession, and was killed in 1686 . Poora's son, Kanowja, was a very bold and spirited leader and became the most noted of the Angria family. About I7I3 he began persistently to harass the English, and on this account several expeditions were sent against him from Bombay. He had, however, by this time established himself in a very strong position at Gheriah and was able to resist the efforts of the East India Company with ease. Kanowja died in 1740 and left two sons, Sambub and Toolajee, who were a terror to all traders. The end came in $175^{6}$, when Gheriah was captured by Admiral Watson and Colonel Clive, who with a squadron of fourteen men-of-war and a strong military force utterly routed out and destroyed the pirate fleet. A full account, no doubt, of this event reached Muscat shortly afterwards, and the news was naturally received with much rejoicing by the merchants.

It is fair to conjecture that Hyder Naik, who throughout his eareer had missed no opportunity of showing his enmity to the English cause in India, was actuated by the same spirit in sending a diplomatic vol. II. 
agent to Muscat, as he might hope thereby to gain the Imam over to the French and Mysore alliance. Ahmed bin Saeed was, however, too prudent and sensible a man to allow himself to be entangled in this way, though, as the course of events during the remainder of the century proved, the Mysore agents were not without political influence in Oman.

It was very soon after his accession to the Imamate that Ahmed made known his intention to follow the policy of his Yaareba predecessors, in refusing to allow the English to build a factory at Muscat. Towards this end negotiations had been carried on intermittently for nearly a century between the English in Western India and successive Imams, but to no purpose, as the Arabs remained firm on this qoint. The decision was probably due to native experience of Portuguese and Dutch encroachments in the Persian Gulf during the seventeenth century. But it was not only the English who were denied a factory ; the Dutch and even the French were treated in the same manner and kept at a distance. The French do not appear to have commenced trading operations in the Persian Gulf before the early part of the eighteenth century, when they located an agent at Busra ; their vessels constantly touched at Muscat, however, during this period, and their relations with the Oman Government were always friendly. The first communications of a political nature appear to have taken place in 1749, when Ahmed bin Saeed was residing at Aufy, near Sohar, previous to his final contest with Belarab.

About the month of February of that year three French privateers from Mauritius entered the port of Muscat, avowedly with the object of intercepting English merchant ships, although it was well known that France and England were then at peace. The largest of these vessels was the Conde. Finding a large English merchant ship in the cove the privateers very unscrupulously endeavoured to cut her out. The Wali Khalfan bin Mohammed resented this breach of neutrality, opened fire on them with the guns of the fort, and compelled them to sheer off. Thwarted in his attempt on the English ship, the captain of the Conde sailed 
for Gombroon, where he attacked and partly destroyed the English factory. After this exploit he steered for Sohar, where a correspondence took place between him and the Imam Ahmed regarding the affair at Muscat.

About the year I758-59 the Imam, having consolidated his power and gained complete ascendancy over the Oman tribes was able to undertake operations in Al-Sirr, generally known as the pirate coast, in order to reduce to subjection the Joasmees and other warlike tribes, who had hitherto remained entirely independent. The Joasmees, who are a branch of the great Hawala clan, occupying the Persian coast from Gombroon to Ras Berdistan, was so named after Shaikh Kasim, the grandfather of the notorious Shaikh Rashid bin Muttar, who ruled at this time and who resided at Julfar or Ras al-Khyma. The Imam first marched against Khasab, when the Shaikh Hassan bin Abdulla al-Shihoo at once submitted. Whilst at Khasab the Imam heard of a Yaareba revolt in Al-Sharkiyah, and having ordered Khalfan bin Mohammed to proceed to Julfar with all his ships, started at once for Jaalan, where he gathered the tribes and suppressed the revolt with a strong hand. On his return to Khasab, the Imam found it advisable to replace Khalfan by a more energetic officer, and he, therefore, summoned Seyyid Ali bin Saif and dispatched him with four ships and ten dhows to Al-Sirr, with orders to establish a strict blockade. These orders were followed up so closely by stopping the pearl-fishery and intercepting trade that in course of time he reduced all the ports on that coast and made them, with the exception of Julfar, recognize the supremaey of the Imam.

This satisfactory result took place in 1762 , and in the following year Shaikh Sakar, with his uncle, Abdulla, and Mohammed bin Ali, proceeded to Rostak, where at an interview with the Imam it was arranged that the blockading fleet should be withdrawn and that the Joasmee port of Julfar should be considered independent of the Imam's authority. The political state of affairs then outlined remained unaltered for more than twenty years.

In the year $\mathrm{r} 76 \mathrm{I}$ another French privateering expedition, conVOL. I. 
sisting of the Boulogne, I4 guns, with a smaller vessel as consort, arrived at Muscat from Port Louis. The Boulogne was commanded by Count D'Estaing, who had accompanied Count Lally to India, and had been taken prisoner by the English at the siege of Madras in November, 1758, and sent to England. Having been liberated on parole soon after, he returned to France, where he broke his parole and sailed for the Mauritius, and with the view of taking his revenge on the English, fitted out a buccaneering expedition to injure their trade in the Persian Gulf.

At Muscat Count D'Estaing followed the example of the Conde, by ignoring the laws of neutrality and attacking an English ship, but the Wali Khalfan bin Mohammed saved the vessel and avenged the insult to his flag by firing on the Boulogne and driving her off.

Proceeding to Gombrocn D'Estaing broke open and plundered the English factory, took several prisoners and then sailed for Sumatra, from whence he returned to the Mauritius.

About this time may be dated the commencement of the Muscat trade with Mauritius, which had been taken possession of in I7I 5 by the French. The first trading vessel from the island probably dropped anchor at Muscat in the time of the Imam Ahmed, and the trade continued without interruption for about fifty years, but it never rose to any great proportions. The article chiefly exported to Arabia was sugar, the island receiving in return salt fish, dates, and coffee. The governor, M. Malartic, used to send acceptable presents of cannon and gunpowder to the Imam, who dispatched suitable gifts in exchange. In 1764 the famous traveller, Carsten Niebuhr, arrived at Muscat from Bombay and remained for some time collecting information respecting the Imam's dominions, though, as he tells us, he did not visit the interior; his map, though of course crude, is the first ever published of the country. The Imam had four ships with which he traded with his own possessions in East Africa, while the revenue derived from the Customs at Muscat was about a lakh of rupees-Europeans paid five per cent. and Arab traders paid six per cent. 
At the close of 1769 Kereem Khan demanded from the Imam Ahmed a large ship, which had been purchased by the latter from the Governor of Hormuz, on the ground that it belonged to Persia, and further required him to pay arrears of tribute which had not been received for many years, but both these demands were peremptorily refused. The Imam's reply as regards the tribute was to the effect that it had been exacted from Oman by Nadir Shah, who could not be denied, and that if Kereem Khan wanted it he must be prepared to take it by force. In $17 ; 6$ Almed sent a fleet with 5,000 men on board to the Gulf to operate against Bushire, to compel the restitution of certain property detained by the Persians, but the expedition proved abortive as it never reached its destination and returned to Muscat.

In 1772 Shaikh Rashid was in alliance with the Imam and cooperated with Khalfan bin Mohammed, Governor of Muscat, against the Persians, and did some damage in destroying galleots. The Shaikh continued to assist the Imam in the war with Persia, which dragged on languidly until I774, when Nasir Khan, Governor of Bushire, was directed by the Shah to prosecute the campaign vigorously or to make terms with the Imam. The Persian terms offered were so preposterous that the Imam rejected them and again refused tribute. It was while engaged in this war that the Imam Ahmed undertook an expedition to Busra, which, though of little avail, redounded much to his personal credil and renown.

Late in the year 1774 the Shah of Persia, Kereem Khan, becoming jealous of the increasing opulence and importance of the city of Busra, which was largely diverting to itself the trade of India formerly flowing to Bundar Abbas and other Persian ports, and alarmed also at the mutinous spirit of his soldiery, resolved to gratify his ambition on the one hand, and give his troops employment on the other, by making war on Turkey and in taking possession of Busra.

Seeking a pretext for his action, Kereem Khan demanded the head of the Wali of Baghdad, Omar Pasha, who had offended the Persians by levying a poll tax on the Shihr pilgrims to Najaf and vOL. II. 
Kerbela. Another pretext was the aid given by the Pasha of Baghdad to the ruler of Oman in $\mathbf{1 7 4 3}$, which, it was averred, prevented the Persians from subduing that province. The head of Omar Pasha having been refused by the Sublime Porte, which had itself issued orders to him for the collection of the tax, the Shah declared war and began to concentrate an army at Shiraz. Intelligence of the Shah's intentions reached Busra in January, I775, and the Mutasalim, or governor, of that city, Suliman Agha, at once reported the matter to the Wali of Baghdad, Omar Pasha, who being then in a critical position was unable to afford any assistance. However, he addressed an urgent appeal to the Imam of Oman for a powerful fleet to oppose the Persians and protect Busra, and to this appeal the Imam sent a favourable response, promising to bring a fleet to the aid of the Turks.

The Persian army, commanded by Sadik Khan, a brother of the Shah, arrived at Howaza in March, crossed the Shat al-Arab in April, and encamped near Marghil. Its strength is estimated at 50,000 men by Abraham Parsons, who was at Busra at this time, and who gives many details of the siege. He tells us in his book of travels that the English Resident, Mr. Henry Moore, was supported at Busra by two of the East India Company's war vessels, viz., the Eagle, I4 guns, commanded by Captain Anderson, and the Success, ketch, 9 guns, besides two ketches of 14 guns each, built for the Pasha in Bombay, commanded by an English midshipman under British colours. At the request of the Mutasalim, or governor, of the town, Suliman Agha, these vessels were ordered to prevent the passage of the Shat al-Arab by the Persian army, as far as lay in their power. With this view they first proceeded to assist the Turks in obstructing the passage of the Persian transports by laying a cable, part of which consisted of an iron chain seventy fathoms long, supported on boats, across the river. This cable, however, was soon broken by the tide and proved of little avail. The Eagle and Success for some time acted vigilantly and fired on the Persian vessels coming up the river, and in this way did some execution, but shortly after, under verbal instructions given apparently to avoid complications, they sailed to Bushire, where they found seven English ships at anchor. 
On board the Eagle was Mr. Green, a former Resident at Busra, who had been taken prisoner in the brig Tiger when it was captured by the Persians about two years before, and had returned to Busra on parole to receive his property. While the siege and blockade of Busra were proceeding, the Imam Ahmed, in fulfilment of his promise to Omar Pasha, continued the preparation of his naval armament at Muscat, and in the middle of August, 1775, received reports of its being ready for sea. It was composed of the Rahmani, on which the Imam himself embarked, nine other square-rigged ships, seventy galleots and trankies, and fifty dhows full of men. Passing Bushire on September IIth, the fleet anchored in the Shat al-Arab, off Deep Water Point, a few days later. The motives of the Imam in undertaking this costly expedition were partly to cement friendly relations with the Turks, to whom he owed some gratitude for help afforded during Taki Khan's invasion, and partly to strike a blow at the Persians, with whom he was at war, and it was not without a feeling of disappointment that he found the Turks much weaker and the Persians much stronger than he had anticipated. After breaking through the iron chain which the Persians had thrown across the river to bar its progress, the fleet attacked and dispersed the Persian galleots under Shaikh Nasir, the governor of Bushire, and was thus able to pour supplies into the town, which was in dire straits from want of fond. But beyond this, little appears to have been done and Suliman Agha's hope of being able, with the help of his Muscat allies, to compel Sadik Khan to raise the siege, had to be abandoned. The Imam then vainly endeavoured to mediate for peace between the two powers, while Hyder Naik's envoy to Persia, who arrived at this juncture in the Persian Gulf from India, seems to have been prepared to do the same.

The Imam had serious thoughts of sending his second son, Saeed, to Kereem Khan to make peace for the Turks, as well as for himself, but this scheme was not carried out, and the Imam Ahmed returned to Muscat with his fleet at the end of the year 1775 .

The unfortunate Omar Pasha had in the meantime been sacrificed to the anxiety of the Sublime Porte to appease the Persian monarch, 
having been beheaded in the month of July, I775. As a sequel to the above narrative it may be mentioned that in 1778 Captain Anderson of the Eagle was directed by the Resident at Bushire to embark on board his ship to Muscat a Turkish envoy with a letter of thanks for the valuable aid given by the Imam during the siege of Busra, and promising that a subsidy should be paid annually to the Oman Government for the service rendered. In the year 1775 the Imam Ahmed and Shaikh Rashid bin Muttar, the Joasmee, were again at war, the Joasmees having become more powerful than ever both by land and sea. Two years later, however, in 1777 , Shaikh Rashid resigned the leadership from old age and infirmity and was succeeded by his son, Sakar, between whom and the Imam Ahmed a truce was made shortly after.

In July, 1775, H.M. Frigate Seahorse, 20 guns, commanded by Captain Farmer, anchored at Muscat from Bushire and remained about two months. It is interesting to remark that one of her midshipmen on board was the future hero of the Nile and TrafalgarHoratio Nelson. It was probably about this time that the Imam Ahmed despatched his frigate, the Rahmani, to Mangalore to enquire why the export of rice had been prohibited, as the want of it was very greatly felt in Oman. The envoy sent in the Rahmani was well received by the representative of Hyder Naik at Mangalore, who explained the cause of the non-shipment of rice to foreign ports. Some time afterwards Hyder Naik sent a return envoy to Muscat, with instructions to sign a convention with the Imam, and to remain there as Mysore political agent. For this agent a house was built at Muscat, and exists there to this day under the name of the Bait alNawab, or the Nawab's house. Salil bin Rizak, who gives the date of this voyage as about 1776 , states that after leaving Mangalore, the Rahmani proceeded to attack a pirate nest and destroy it.

In May, I778, a third breach of neutrality was committed by the French : an English merchant ship bound to Bushire from Surat, with a cargo of 500 bales of cloth on board, was chased by a French privateer in the Gulf of Oman, and ran for shelter into Muscat. The privateer followed and endeavoured with her boats to cut her out, 
but the Wali Khalfan bin Mohammed protected her, and not only sent a letter of protest to the aggressor but opened fire, and the Frenchman, after a loss of five killed, desisted from the attempt and sailed away. About a month subsequent to this event, war broke out again between the Imam and his persistent enemy the Joasmee, who had taken some Persian ships on the plea that they had Muscat property on board. They soon after joined Shaikh Nasir at Bushire in trying to recover Bahrain from the Attoobees, and their ships became very active in the Gulf at this time, committing acts of piracy and insulting the Muscat coast. Shaikh Sakar, who, as we have seen, succeeded his father in 1777, was indeed so bold and troublesome in his depredations that the Imam soon found it necessary to undertake operations against him. In November, ${ }_{177} 8$, therefore, a fleet consisting of twelve ships and a hundred smaller craft were dispatched to Julfar. In consequence, however, of the shallowness of the water preventing the larger ships approaching within two or three miles of the shore, their guns could not reach the town, and the demonstration failed in its object. In the following month Shaikh Sakar marched with a large force to raid the Batineh and besiege Rostak, but nothing resulted from this campaign and he soon after returned to Julfar. It was while Shaikh Sakar was engaged on this expedition that the first recorded instance of an attack by the Joasmees on an English ship occurred. In December, I778, an English snow (i.e. brig) with despatches on board and manned by an European master and mate with a crew of Lascars, was met in the Gulf by six Joasmee dhows, and after a stubborn fight of three days, in which thirty Arabs were wounded, was captured and taken into Julfar. The Resident at Bushire, Mr. Beaumont, tried to ransom her, but the Shaikh refused to surrender her for less than 4,000 rupees.

In January, 1779, the ketch Success on her way from Muscat to Busra was attacked by eight or ten Julfar dhows, but luckily repulsed her assailants and escaped. In the following month the English snow Assistance, commanded by Captain Johnston, was attacked by Julfar pirates, but having taken the precaution to take 
in some Belooch soldiers at Muscat, she beat off the pirates and arrived at Bushire in safety. The war between the Imam Ahmed and Shaikh Sakar continued to be carried on with unabated vigour at this time. The Joasmee piratical vessels cruised in the Persian Gulf and Arabian Sea and committed great depredations in spite of constant efforts of the Muscat fleet to suppress them, and they did not hesitate to attack European ships whenever they thought they could do so with success. Great anarchy prevailed, as all the various tribes in the Gulf seemed to be at variance and peace was not restored until $I_{7} 85$. One of the serious troubles that befell the Imam Ahmed and perplexed him in his old age was the ungrateful and contumacious conduct of some of his sons, who at this period began to quarrel among themselves and to intrigue with the more powerful 1ribes about the succession.

The Imam's eldest son, Hilal, was now blind and incapacitated for rule; Saeed, the second son, was a man of weak, indolent, and voluptuous character-his father had given him the Wilayet of Nezwa, where he made himself very unpopular by his exactions and oppressions; Kais, the third son, was headstrong and ambitious and inclined to give trouble, but as the Imam prudently presented him with the Wilayet of Sohar, he did not concern himself much with the quarrels between his brothers that disturbed his father during the later years of his life. The next two, Saif and Sultan, were the most unruly of the Imam's children; being descended through their mother from the ancient and noble Jiboor tribe, they considered themselves as having a higher claim to the succession than their brother Saeed, of whom they were very jealous and whom they had long feared and detested. Apprehensive of the approaching end of the old chieftain, they began an intrigue with the Joasmee, Naeem, and other powerful tribes in order to gain their support in the coming struggle. The first overt act of insubordination towards their father occurred in the year I780. Having obtained the assistance of a small party from Nakhl, the two brothers made a night attack on the fort of Burka on the Batineh coast.

In spite of a strong defence, in which the governor was killed, 
an entry was forced, and possession gained. As soon as the news reached the Imam, he set out to vindicate his authority and compel the surrender of the offenders. The fort was bombarded and after a long resistance the sons came out to crave forgiveness of their father; this was at once granted and the troops returned to Rostak.

The fact of Saif and Sultan having been assisted in their adventure by a party from Nakhl naturally caused the Imam to throw the blame on the governor of that town, Mohammed bin Suliman al-Yaarebi, who, it will be remembered, had been given that district as an appanage on the death of Belarab bin Himyar in 1749 . Rejecting Mohammed's protestations and disavowals of his complicity in the matter, the Imam collected an army to punish him and soon appeared before the walls of the fortress. Mohammed, however, had strong partisans in the Naeem and other tribes of Dhahireh, and Nakhl was so well guarded that the attack proved a failure. The Imam's force gradually melted away and he returned to Rostak discomfited. He then turned his attention to the Batineh and led an army to Hazm, where the Yaareba and other tribes had revolted, and having obtained some success, he recovered his prestige to a certain extent, and then returned to the capital.

In I78I three French privateers from Mauritius, one of 36 guns, commanded by Captain De Cheny, one of II guns, and one of I4, came to the Gulf of Oman, and having captured on the way an English ship the Beglerbeg, commanded by Captain Peter Scott, bound from Surat to Moocha, entered the cove of Muscat. After a vain attempt to seize an English ship at anchor here, the privateer sailed up the Gulf, and on June $15^{\text {th }}$ captured off Sohar, after a short engagement, the Imam's frigate Salih, of 50 guns, laden with goods from a British Indian port to Busra. With a prize crew on board the Salih was sent to Severndroog, and there sold to the Mahrattas. One of the Salih's boats having escaped capture brought the news to land, and a message was at once dispatched to the Imam to inform him of the event. Two months later, one of the privateers happened to return to Muscat for refreshments and the 
Imam immediately ordered her to be seized and her crew made prisoners in retaliation, but shortly after this order was reversed and the Frenchmen were sent to the Mauritius together with an envoy, who was instructed to demand restitution of the Salih and her cargo, which was valued at twelve lakhs of rupees. The mind of the Imam Ahmed was deeply wounded by the action of the French, for whom he had always felt much cordiality and for whom he had always shown great consideration. This unjustifiable proceeding almost caused a temporary rupture of friendly relations, and the Imam immediately addressed strong remonstrances, not only to the Mauritius, but the French Government, through the medium of his friend, Monsieur J. F. X. Rousseau, the Consul-General at Baghdad. This gentleman, who was born and brought up at Ispahan, entered the French consular service and proved himself a good diplomatist and linguist. He had been for many years in communication with the Imam Ahmed and had much influence with him. He represented the case fully to the French Government at Paris, who eventually expressed regret at the occurrence and purchased a ship, called the Courier de l'Isle de France, to be sent out to Muscat to replace the Salih. This was accordingly done, but the promised vessel was taken on the way by an English cruiser, and it was not until the year I79o that a second small vessel, called the Escurial, but re-named the Salih, was convoyed to Muscat by the La Thetis, frigate, commanded by Captain Macnamara and delivered to the Imam Saeed. Captain Macnamara is said to have negotiated, under instructions from the French Foreign Office, a convention with the Imam, but it seems to have been confined to expressions of mutual friendship and goodwill.

Going back to the month of February, I78I, we find that Saif and Sultan, who were residing in the small castle of Naaman, near Burka, being eager to put themselves in an independent position, resolved to make a desperate effort to possess themselves of Muscat, and made good plans which at first seemed to promise success. Having solicited the support of the Beni Jabir, they proceeded to Muscat with a small party and requested permission to enter the town, and were 
unsuspectingly admitted by the governor, who recognized them as sons of the Imam Ahmed. The two brothers then lost no time in seducing the commandants of the two forts, Merani and Jelali, of which they thus obtained possession. The Wali, finding himself deceived, at once apprised the Imam of what had occurred, and endeavoured to recover the forts, but Saif and Sultan opened fire on the town and soon laid part of it in ruins.

Incensed at the news the old Imam quitted Rostak with a large force to reduce his rebellious sons to obedience, and on arriving at Muttrah ordered the merchants and inhabitants of Muscat to bring their effects to the former town for security. He then demanded the surrender of the forts, and on this being refused he commenced hostilities. In the meantime Saif and Sultan despatched letters to Shaikh Sakar, the Joasmee, to solicit assistance, which request was readily complied with. Shaikh Sakar, however, instead of joining the brothers at Muscat, deemed it more politic to march direct on the capital, and gathering contingents from the tribes on the way, arrived there in April, I78r. This diversion had its intended effect; the Imam, dreading the Joasmee invasion, made peace with his sons and agreed that each of them should retain one of the forts, and further, that there should be an amnesty to all concerned.

For some reason the Imam shortly after changed his mind and retained Merani for himself, allowing his sons to hold Jelali between them. Tranquillity for some months ensued, and then another and more serious effort was made by Saif and Sultan. Having decoyed their brother Saeed to Naaman Castle, they treacherously seized and bound him, brought him down by boat to Muscat, and threw him into a dungeon in Fort Jelali. Divining, rightly, no doubt, that Saeed's life was in danger, the aged Imam hurried down from his capital at the close of December, and passing Naaman on January Ist, 1782 , arrived at Muscat, where he occupied the old Portuguese " gareza," or cathedral. On the refusal of his sons to surrender, the Imam ordered the Commandant of Merani to open fire on the fort of Jelali, and a vigorous bombardment ensued which was supported by the Imam's ships of war lying to the eastward. The heavy crossfire to 
which Jelali was then subjected would soon have compelled submission, but in the meantime, Saeed, having bribed his gaoler, managed to escape from the fort by being lowered by a rope on to the rocks below during the night, and was able to rejoin his father in the town. Having gained his end by the sudden deliverance of his favourite son from the prospect of a cruel death, for the usual custom among the Arabs in such cases is to let their victims come to a tardy and lingering fate by starvation, the Imam at once put a stop to the bombardment and offered terms to Saif and Sultan, who, after the loss of their hostage, Saeed, had nothing to expect from prolonged hostilities, and had no resource but to yield the fort. With a view to prevent any further acts of rebellion on the part of his two sons, the Imam, on leaving Muscat, took Saif with him in custody, and detained him under surveillance for many months at Rostak.

The remainder of Ahmed bin Saeed's active and stirring life was calm and uneventful. He died at an advanced age at Rostak on December 15 th, I783, after a reign of thirty-four years, and was buried near the Great Mosque. His tomb bears a long inscription, of which after quotations from the Koran, the following is a translation :-

" This is the grave of our Master our Seyyid, the light of our darkness, the Imam, the just, benevolent, the perfect, the learned, the worker, the pious, the devout, the ornament, the Imam of Mohammed, the administrator, of the Faithful, the banner of fighter in the cause of religion, the Imam of Mussulmans.

"Ahmed bin Saeed bin Ahmed bin Mohammed bin Khalif bin Saeed al-Boo Saeedi, the Azdi, the Omani, the Ibadhi. May God have mercy on him and pardon him.

" His death occurred on the morning of Monday the nineteenth of the month of Al-Moharram in the year one thousand one hundred and ninety-eight. Igth Moharram, IIg8 A.H." [A.D. I783].

On the death of the Imam, the Kadhis and Shaikhs assembled at Rostak, and in accordance with the expressed wish of their great 
prince, elected his second son Saeed to succeed him. No opposition was offered to this election at the by any member of the family, and Saeed, having taken quiet possession of the capital, Rostak, assumed the administration. All the forts that were in the possession of Ahmed submitted to Saeed unreservedly, the three forts of AlHazm, Nakhl and Sohar, remaining in the hands of the Yaareba, Mohammed bin Suliman and Kais respectively.

The change, however, that soon took place in the affairs of Oman was lamentable ; the land that had been so well and firmly guided by Ahmed fell now, in the hands of the weak and incompetent Saeed, into a state of confusion and anarchy, and the fierce animosities and jealousies of the tribes burst forth without restraint ; the most prominent consequences perhaps of the change being the triumph of political ascendancy from the Hinawa faction to that of the Ghafiris.

Though Saif and Sultan did not oppose the election of their brother, they well understood the danger to which they were exposed from that quarter, and lost no time in appealing to their friend, Shaikh Sakar, the Joasmee, to help them in dispossessing Saeed of the Imamate. The appeal was not made in vain. In I784 Shaikh Sakar, having gathered the Shemal tribes, declared war against the Imam, and soon captured the towns of Hamra, Shargah, and Rams, as well as Khor Fakan.

The Imam's operations against the Joasmees and their allies were conducted with much vigour by land and sea, and the war continued for some time, but the towns taken by the latter were not recovered; the campaign terminated without any material success having been gained by the Imam.

The failure of the efforts of the Joasmee Shaikh to overthrow Saeed and to establish Saif as Imam in his stead was a bitter blow to the two brothers, who now felt that it was placing their lives in jeopardy to remain any longer in Oman. Saif accordingly sailed for East Africa and landed first at Lamoo, where the Imam's government was not represented, with the intention of subverting Saeed's authority on that coast, and forming for himself an independent kingdom. His intrigues and influence advanced so rapidly that Saeed, becoming voL. 11. 
alarmed, sent his son Hamed with a small force to counteract him, but as Hamed learned on arrival that Saif had died shortly before, he returned home.

Quitting Oman at the same time as Saif, Sultan sailed to Gwader on the Mekran coast, from whence he proceeded to Kelat to seek the hospitality of Nasir Khan. The Belooch ruler not only received him honourably and accorded him protection, but also presented him with the town and harbour of Gwader, with permission to retain half the revenue as appanage. This port remains in possession of the Muscat government to this day.

On September Ist, I785, three French men-of-war arrived at Muscat from the Mauritius, which place they had left in June of the same year. The largest of these was the Venus, frigate of 44 guns, commanded by the Count de Roselie; the second was the Prévoyance of 8 guns, commanded by Chevalier Saulnier, and the third the Amphitrite, also of 8 guns, commanded by Captain Lambert. In the interview with the Wali Mohammed Khalfan, Count de Roselie announced that he had been entrusted with a mission to obtain the Imam's sanction to the building of a factory at Muscat by the French East India Company, for the furtherance of their trade. The Count also, doubtless, conveyed the congratulations of the King of France to Saeed on his accession, the news of which had been duly notified at Paris by Consul-General Rousseau. The Count's request to erect a factory was met, like all previous applications of a similar nature, by a courteous but positive refusal, the Wali informing him that the Imam's orders on the point were irrevocable and that it was useless to press the question. On leaving Muscat the Venus sailed for the Persian Gulf and visited Busra and Bushire.

As time went on the Imam's conduct became more obnoxious to the people than ever. He took no pains to win their affection and gradually estranged most of his friends and adherents. This discontent went so far that about the end of the year $x 785$ a number of Khadhis and Moollas assembled at Mesnaah, on the Batineh coast, and elected his brother, Kais bin Ahmed, as Imam. Notwithstanding his election, Kais could claim but few partisans and looked round him 
for further support. In hopes of obtaining the aid and co-operation of Mohammed bin Suliman, Kais moved up without delay to Nakhl. but found to his disappointment that Mohammed was averse to joining in the enterprise against the Imam Saeed, and the revolt consequently collapsed.

Soon after this event the Imam Saeed was induced to interfere in a serious quarrel that had taken place among the people of Zikki, who were then, as they are now, divided into two hostile camps. Each faction occupied a separate Hujrah or walled town. In this contest the Ghafiris were utterly defeated by the Imam and the Hinawas, who were able to impose their own terms. On January Ist, 1787, an Arab ship cast anchor at Muscat, having on board Captain Francklin and several other English officers on their way to Persia. One of these, Captain Middleton, of the Madras army, died here, and at his funeral a salute of nine guns was fured by the vessels lying in the harbour, viz., an English snow and a Dutch ship, commanded by Captain Stewart.

Captain Francklin gives a good description of the town and remarks that it has a considerable trade with other countries, but that the Arab government would not permit any European factory to be established here. Although the efforts of Kais to supplant his brother Saeed had proved a failure it was manifest that the Imam was unfit to rule alone, and that the main work of the administration must devolve on others.

Hamed, the eldest son of Saeed, was the one who naturally came forward to undertake this task, and being unable to induce the Imam to abdicate, began during the year $\mathrm{I} 786$ to have recourse to intrigue. By a series of crafty and unscrupulous devices, the particulars of which are given in Salil bin Rizak's pages, Hamed obtained possession first of the town and fortress of Muscat from Mohammed bin Khalfan, and subsequently the deliverance to him of the fortresses of Oman, one after another.

Within three years the Imam's temporal power in the state had slipped completely from his grasp and became centred in the hands of his son, who fixed his residence at Muscat and henceforth, as voL. II. 
Regent, carried on the administration with ability and firmness. At this time the Joasmees were very active in the Gulf, being at war with the Attoobees, who had recently taken the Island of Bahrain from the Persians. Shaikh Sakar's efforts, however, to recover the island, in co-operation with the Persians, were ineffectual. In 1787 the Joasmees were again at war with the Imam, and Hamed moved towards the Shemal, by land and sea, with a large force, the fleet being commanded by Mohammed bin Khalfan. In this expedition Hamed was so far successful that he retook Khor Fakan, Jezirat al-Hamra, and laid siege to Rams. He then appears to have returned home, leaving the fleet to operate against Julfar. It is worthy of note here that three years later (r790) occurred the first capture of an English vessel by the Joasmees-this ship was the Beglerbeg, bound from Bengal to Bushire, which was taken off Mussendom, where she remained on the rocks for many years.

We must now return to Sultan bin Ahmed who, after an exile of five or six years at Gwader, thought he might prudently venture to return to Oman under the leaders of the Ghafiri faction, with whom he had probably been in communication. Though Sultan's tribe, the Al-Bu Saeedi, was the Yemen or Hinawi faction, Sultan himself always mainly relied upon, and had been supported by, the Nizar or Ghafiri faction, his mother being a relation of Mohammed Nasir al-Jabry, who was one of the most prominent leaders of the Ghafiris.

On landing in Oman Sultan bin Ahmed probably took up his old residence at Naaman, near Burka, and gathered near him a sufficient following to protect himself from the enmity of Hamed, who was still as rancorous towards him as ever. As soon as Sultan had ascertained the exact condition of affairs in the country he arranged with the Beni Jabir and other Ghafiri tribes in the Semail Valley to attack the fortress there and wrest it, if possible, from the hands of Hamed, in whose possession it then was. Hamed quickly collected a force and marched to Semail, but finding his uncle in an excellent position and at the head of a force equal to his own, contented himself with watching his enemy, and no collision took 
place. Hamed then allowed his troops to disperse and proceeded to Rostak, to see his father, while Sultan took the opportunity to push down to the coast and plunder Muttrah. The loot was carried to Darseyt, whither Sultan was pursued by Suliman bin Khalfan, now Wali of Muscat, but the attempt to recover the booty was in vain. No further desperate passage of arms arose between Hamed and Sultan, and shortly after a reconciliation was arranged, which was stedfastly and faithfully observed on each side.

Hamed seems to have been a man of remarkable character with a mind equally bold and subtle, and whose head was ever full of ambitious and aggressive schemes. One of his mischievous plans was to raid the Island of Bombay, by letting loose some thousands of wild Arabs on the native town and bazaars; this enterprise, if carried out, might have led to curious results, but fortunately it never went beyond Hamed's brain. Another scheme was to try and recover Mombasa from the Portuguese, but this campaign was reserved for Sultan. It appears certain that in I79I-2 Hamed's mind was busily engaged in working out the plan of a military expedition, and he was preparing ships and transports, as well as collecting men from the tribes, when his career was terminated by death; he died at Muscat of small-pox in I792.

The unexpected death of Hamed changed the whole aspect of affairs and roused the Imam Saeed from his lethargy. Though content to leave power in the hands of his son he had never tolerated the idea of giving way to his brothers and now that the burden of rule had again fallen on his shoulders, felt compelled to resume charge of the administration. Sultan, however, who had been impatiently watching events, now felt that the tide had turned in his favour, and determined to seize the opportunity offered by the death of Hamed, to obtain his long-cherished object and desire.

Calling on his relative, Mohammed Nasir al-Jabry, and other friends and adherents to support him, he set out for Muscat, of which he soon became master almost without resistance. Feeling strong in his influence and prestige, and commanding the undivided support of the Nizariyeh or Ghafiri faction, Sultan was now confident vol. II. 
of success and spared no efforts in preparing to meet his brothers and rivals, the Imam Saeed and Kais, in the field. The vigour and promptitude of Sultan had excited the jealousy and fears of his brothers who now made common cause, and uniting their forces marched from Rostak and Sohar upon Muscat. But the way was barred by the Ghafiri tribes, and a contest took place, which lasted for some months, without any decisive action taking place. By the end of the year the threatened upheaval of the country by a contest for the succession was averted. Kais, despairing of success, retired from the struggle, and at a conference of delegates assembled at Burka, it was arranged that the Imam Saeed should remain at Rostak as the religious head of the nation, that Kais should retain Sohar as his appanage, that Sultan should have Muscat, Burka, Mesnaah, with the entire control of political affairs, and that Mohammed bin Ahmed should keep Sowaik. This compact, which was not unsatisfactory to the people generally, was accepted by all parties and peace was then restored throughout Oman.

Sultan was born about I755, probably at Rostak, and in his childhood was sent to Adam, where he passed the years of his youth among the Bedouins in the neighbourhood. $\mathrm{He}$ is said to have been tall and of a noble presence, undaunted in courage and of sound judgment, not inferior in any way to his father, of whom he was a worthy successor.

Taught by experience during the Persian invasion the high value of Muscat, the statesmen of Oman had by this time perceived that its unrivalled position as a port and as a natural fortress against external and internal foes made it a far more suitable capital than Rostak, Nezwa, or Sohar, and Sultan, following the example of Hamed, lost no time in establishing the seat of government in that city. As a residence he fixed upon the gareza, or cathedral, a large Portuguese building, and here he dwelt for about seven years, when the present palace and seraglio were built.

One of Sultan's first acts after coming to power was to despatch a trusted relative with a suitable force to Gwader to occupy that place on his behalf and to build a fort. The officer was Saif bin Ali, who, 
in accordance with further instructions, subsequently surprised and took possession of the village of Charbar, about roo miles to the west of Gwader.

With his ambition fed by this success, Sultan next sent an expedition against the Beni Naeem of Kishm and Hormuz, who had given him much provocation. This enterprise he commanded in person and with such skill that his conquest of the islands was complete. At this time, and for some years previous, the Shaikh of the Naeem was the Governor of Bundar Abbas and its dependencies, the revenues he had farmed from the Persian Government for a fixed yearly rental. The result of the war was thus doubly advantageous to Seyyid Sultan, for he now assumed the position of the Shaikh, as regards his relations with the Persian Government, and after some negotiation obtained a firman in his own name from the Shah, by virtue of which, on a yearly rental of 6,00o tomans, Bundar Abbas remained a dependency of Muscat for three-quarters of a century. As Persia and Oman were at this time (1794) on bad terms, Seyyid Sultan had, no doubt, to submit to pay heavily for this concession. Soon after Sultan's return from this expedition a quarrel arose between Kais bin Ahmed and some of the Shemal tribes, such as the Beni Yas, Kattab, and Naeem, who moved up to threaten Sohar. Kais being unprepared to meet them, implored Sultan's aid in this emergency, and Sultan having rapidly concentrated a force, joined Kais and marched against the enemy. A heavy fight took place at Dibba, on the same field as the famous battle of A.H. II [A.D. 632], and the victory remained with Kais and Sultan, the Naeem being utterly routed and dispersed.

For some years tranquillity prevailed, not only throughout Oman but in the Persian Gulf. Hitherto the rulers of Oman had observed neutrality and had not materially interfered in Gulf affairs, but in I796 a rupture occurred with Persia, where the vigorous hand of the founder of the new Kajar Dynasty, Agha Mohammed Khan, was being felt in every part. The Shaikh of Bushire now received orders to embark a military force at Mohammerah for an attack on Muscat, but the order appears to have been disregarded owing to want of means. 
On May 18th, 1797, the Bassein snow, commanded by Captain Torin, bound for Busra with despatches, was attacked off Kishm by twenty-two pirate dhows and carried by boarding. After being plundered and detained for two days she was released and allowed to continue her voyage.

About six months later, in October, a most flagrant case of treachery and unprovoked hostility was committed by the Joasmees against an English cruiser. The Viper, of Io guns, was anchored in Bushire harbour, where there was a fleet of Joasmee dhows lying in wait to intercept some Sooree boats coming from Busra. The Joasmee chief, Shaikh Salih, called on the Resident, and after many protestations of friendship asked for a supply of powder and shot. With incredible weakness the Resident consented and gave the order to the Viper to furnish it accordingly. The Joasmees had no sooner received the powder than they opened fire on the Viper and attempted to board her. The officer in command, Captain Carruthers, was struck down by a bullet in the head, but the midshipman, Mr. Salter, continued to fight and eventually repulsed the assailants, chasing them out of sight. But the loss of the Viper with thirtytwo killed and wounded out of a total of sixty-five, shows how severe the action had been and how narrowly she had escaped capture. Still more incredible is the fact that no notice of this treachery was taken, no inquiry made, and no punishment on the Arabs was inflicted by the Government of Bombay. The Resident of Busra, Mr. Manisty, however, sent a strong remonstrance to Shaikh Sakar, but received merely an evasive reply and disavowal of Shaikh Salih's action.

It appears to have been in the year I797 that Saood, the Amir of Nejd, who had embraced Wahabeism and had overrun and converted the greater part of Arabia by the sword, began to encroach on the northern coast of Oman and endeavoured to subdue the warlike seafaring tribes there, namely, the Beni Yas, Kattab, and Joasmees. The tribes, however, resisted valiantly, and for three years the contest was stubbornly maintained, but in 1800 the Joasmees succumbed and accepted the Wahabee doctrines.

During the greater part of 1798 Sultan was busily engaged in 
directing the internal affairs in Oman, but in the month of December he sailed with an expedition against Busra to enforce his claims upon the Pasha of Baghdad for arrears of subsidy. With the view of preserving his territory from insult during his absence from Oman, he made a truce with Shaikh Sakar, the Joasmee, who, being now engaged with the Wahabees, was only too glad to be relieved from hostilities with the ruler of Oman. The Pasha heard of the advance of the Muscat expedition with apprehension, as he had no ships at his disposal capable of contending with the Arab fleet. He therefore solicited from Mr. Manisty, the Resident, the assistance of two English cruisers in protecting his town from attack, promising in return certain advantages in the way of trade. The Indian Government, however, was at this time not in a position to forsake its attitude of neutrality or to make enemies of any Gulf factions, and the Resident was instructed to refrain from doing more than offering good offices in bringing about an amicable settlement. Mr. Manisty accordingly mediated between the Mutasalim of Busra and the Arab leader of the Muscat fleet, which was then lying at Bushire, and effected a complete reconciliation. Perhaps the most important act which Sultan had to do at this period was to make his choice between the two great European powers then contending for the mastery in India-France and England.

Up to this time French influence had been predominant at Muscat and since his usurpation Sultan appears to have acted in some degree under the advice of his French physician. The prestige of France, however, declined in the East during the French Revolution, until the middle of the year 1798, when the sudden appearance of a French army in Egypt, and the brilliant conquest of that country by the young general in command, riveted the eyes of all nations on his surprising achievements. In his dreams of Eastern glory one of Bonaparte's plans was to march across the Syrian desert, then through Mesopotamia and Persia, to the frontiers of India, and to conquer that Empire for France or for himself. It was in pursuance of this project which he continued to cherish for years afterwards, that he despatched emissaries and letters to various Oriental potentates, among whom 
were Tippoo Sahib and the Imam of Muscat, with a view to gain allies and assistance in the enterprise.

Twelve days before he started from Cairo on his Syrian expedition he wrote the following letters to the Imam of Muscat and Tippoo Sahib. The letter to Tippoo was the favourable answer to his repeated requests to the French Government for aid against the English, which the misguided Tippoo had been for so many years expecting. But it came too late; the opportunity had been lost. Tippoo was now at the end of his career, and the letters, instead of reaching their intended recipients, were intercepted by Captain $S$. Wilson, the British Agent at Mocha, who transmitted them to India.

"To the Imam of Muscat,

$$
\text { "Cairo, 25th· January, I799. }
$$

"I write you this letter to inform you of the arrival of the French army in Egypt. As you have always been friendly you must be convinced of our desire to protect all the merchant vessels you may send to Suez. I also beg you will forward the enclosed letter to Tippoo Sahib by the first opportunity.

" To Tippoo Sahib,

$$
\text { " (Signed) Bonaparte." }
$$$$
\text { "Cairo, 25th January, I799. }
$$

"You have already been informed of my arrival on the shores of the Red Sea, with a numerous and invincible army, animated with the desire of delivering you from the iron yoke of England. I hasten to inform you of my desire to receive news with regard to the political position in which you find yourself placed. I even desire you will send to Suez some competent person who enjoys your confidence, and with whom I can confer.

$$
\text { " (Signed) Bonaparte." }
$$

In the meantime the alarm felt by the Indian Government at the undoubted influence of the French in Oman, the dread lest this would extend over the Gulf, and the apprehension everywhere in- 
spired by Bonaparte's military genius and restless activity, led the Governor-General of India, the Marquis of Wellesley, to instruct the newly-appointed Resident at Bushire, Mirza Mehdi Ali Khan, to visit Muscat on his way and to enter into a political engagement with Sultan, having for its object the exclusion of French influence from Oman territory.

Mirza Mehdi reached Muscat in September, 1798, and the treaty which he negotiated was signed on October I2th following. It comprised seven articles and contained, besides the engagement to exclude Frenchmen from the Imam's territory and French ships from his ports, during the prevalence of war between England and France, provision for the establishment by the East India Company of a factory at Bundar Abbas with a guard of 700 or 800 Indian troops. Though it was not mentioned in the treaty, Sultan further made a special request-that an English officer should be sent to reside at Muscat, on behalf of the Company, as his adviser. Sultan was thus the first Prince in the Peninsula of Arabia to enter into political relations with England, and it is satisfactory to note that the friendly relations then initiated have from that day to this continued to strengthen and increase.

During the year 1799 Sultan was engaged in consolidating his power in Oman and in dealing with internal dissensions. Among the tribes that were disaffected towards him were the Daroo of $\mathrm{Al}$ Sharkiya and the Beni Naeem of Al-Dhahireh, both of which he succeeded in subduing, and bringing back to his allegiance. Having at length tranquillized his country, he was able to turn his attention to foreign enemies, and first of all he resolved to concentrate his strength against the Attoobees of Al-Bahrain, who had refused to pay any longer the tax levied upon all vessels passing from India to the Persian Gulf. This sea tax had for one and a-half centuries been paid to Muscat by all craft, foreign as well as home, sailing through the Straits of Mussendom, and as the revenue it used to bring in was considerable, Sultan was not inclined to allow the refusal of the Attoobees to pay the impost to pass without chastisement. He accordingly sailed in the Gunjava frigate, with three square 
rigged ships and sixty bughlas to attack Al-Bahrain, and in a seafight that took place shortly after, captured three of the Attoobee vessels. In the meantime the Attoobees, being aware of their inability to resist the naval power of Oman, had hastened to place themselves under the protection of Persia, by paying the Shah the tribute for Al-Bahrain for the preceding year.

Sultan heard of this action on the part of the Attoobees at the time when he was preparing to land his troops on that island, and he lost no time in entering into negotiations with Persia himself. Being foiled in his attempt on Al-Bahrain, he occupied the Island of Karrack, which he offered to farm from Persia at a yearly rental and pay five years in advance. This offer, however, was declined by the Persians, who continued to take the part of the Attoobees, and Sultan eventually relinquished further operations against the tribe on payment by them of a portion of the arrears of sea-tax due ; of this tax we hear nothing further, and it appears to have been henceforth abandoned.

Not long after the conclusion of the treaty by Mirza Mehdi in I798 reports reached the Government of India to the effect that, notwithstanding his engagements, Sultan had resumed friendly intercourse with the French, and the interception of General Bonaparte's letter seems to have been looked on as affording proof of this. The immunities in favour of Arab trade that had been granted to Sultan were accordingly suspended for a time, and Captain John Malcolm, who had been selected to conduct a mission to Persia, was instructed to call at Muscat on his way thither, for the purpose of renewing the Anglo-Oman alliance and concluding a second treaty, confirming the provisions of the one of 1798 .

Captain Malcolm sailed from Bombay in the Bombay frigate, commanded by Captain Selby, and arrived at Muscat on January 8th, I80o. Besides the staff attached to the mission to Persia, Captain Malcolm brought with him Assistant-Surgeon Bogle, of the Bombay establishment, who, in compliance with the request made by Sultan to Mirza Medhi Ali, had been appointed to act as Resident on behalf of the East India Company at Muscat. On anchoring in 
the harbour the Bombay was visited by the Governor of the town, Saif bin Mohammed, who came to call on Captain Malcolm, and stated that Sultan was absent at the time on an expedition against the Attoobees and that his return was uncertain. Captain Malcolm returned the Governor's visit the following day, and then having landed Dr. Bogle and installed him in his appointment set sail for Hormuz in search of Sultan.

On January I8th Captain Malcolm sighted and boarded the Gunjava off the island of Henjam, and having produced his credentials and delivered his presents, proceeded at once to explain the purport of his mission. He told Sultan how much the Indian Government regretted he had leagued himself with the French, pointing out that as all the ports of India from Surat to Calcutta were in the hands of the English, Muscat could, without difficulty, be excluded from all participation in the Indian trade if the British Government were so disposed.

Sultan listened with deep attention; being conscious of his inability to maintain an attitude of strict neutrality in the war he felt the full force of the arguments put before him, and he had no hesitation in making his decision, replying to Captain Malcolm, His Highness assured him that he desired nothing better than to cement an alliance with the English, to the exclusion of their enemies, and he offered to sign then and there the treaty that Captain Malcolm had been empowered to conclude. The treaty thus entered into bears, in fact, the same date, and consists of only two articles, one confirming the convention of 1798 and the second providing for the residence of a Political Agent.

In November, I80o, another engagement took place in Oman waters between French and English cruisers. The Intrepid of Io guns, commanded by Captain Hall, encountered a French privateer of 12 guns off Muscat, and after a long combat succeeded in beating her off and chasing her away; Captain Hall and five men were killed in the action.

It was in this year-I80o-that the warlike tribes of Nejd, in Central Arabia, were first seen in Oman. These tribes, impelled 
by the fanaticism engendered by the doctrines of a religious reformer, Shaikh Abdul Wahab, after whom they are now called Wahabees, had already overrun and conquered nearly the whole of the rest of the Peninsula, and the Amir Abdul Azeez, eager to expurgate the heresy of Ibadheeism from the land of Oman, was now preparing to turn his arms eastward and spread his views of the true religion by the sword.

After completing the subjugation of the tribes on the pirate coast, the Wahabees pushed on to Al-Beraimi. The leader of this expedition, which consisted of a large camel force and 7oo cavalry, was-Al-Harik, a bold and skilful general, who immediately began the erection of a fort there, to serve as headquarters or as a base of operations and campaigns against the people of Oman. This invasion of their country by the dreaded Wahabees created intense excitement throughout all Oman, and Sultan, with his usual energy and spirit, hastened to assemble the troops and move up to oppose their advance. He marched through the Wady Jezzi as far as Al-Beraimi, but in the contest which ensued with the enemy Sultan appears to have been unsuccessful in his attack on the fort, and finding that he could not expel the intruders from Al-Jow made a truce with Al-Harik and retired to Sohar, where he dismissed his troops.

In I8or the island of Al-Bahrain, which has ever been, on account of its rich pearl-fishery, the chief bone of contention for the peoples round the shores of the Persian Gulf, was again the object of Sultan's ambition, and was invaded, this time successfully, by a grand naval expedition from Muscat, the Attoobees being driven out and the island occupied by the Omani troops, and Saif bin Ali, who had already done good service on the Mekran coast, was appointed Governor and Commandant. An attempt was then made by Sultan to capture the town of $\mathrm{K}$ wait, where the Attoobees had taken refuge, and homage was demanded from the Shaikh, but the enterprise was a failure. Nor did Al-Bahrain remain long in the possession of Muscat; a few months later it was retaken from Salim bin Sultan, then a boy of twelve, who had replaced Saif bin Ali, by the Attoobees, who succeeded in surprising the garrison. In this year Assistant- 
Surgeon Bogle was succeeded by Captain David Seton, of the Bombay Army, who was appointed to act under the title of Resident at Muscat, and who assumed charge of his duties towards the close of the year.

The expulsion from Al-Bahrain was a disappointment to Sultan, whose ardour for military enterprises appears to have been unquenchable, and who now resolved upon prosecuting the Attoobee war in earnest. Saif bin Ali was again despatched with a strong naval force to the island, which, in part, he succeeded in re-occupying, but though he made good his footing, Saif could not entirely expel the enemy, and Sultan, feeling his strength unequal to their subjugation, supported as they were at this time by the Wahabees, now determined to call in the aid of Persia. With this object he despatched as envoy, one Shaikh Ali, by way of Congoon to the Prince-Governor of Shiraz, with costly presents, to procure the co-operation of that ruler in a great expedition against the Attoobees. Sultan wrote also to Shaikh Nasir, the Wali of Bushire, requesting him to use his influence with the Prince in obtaining the required assistance, and enclosing a blank sheet of paper with his (Sultan's) seal on it, to be filled up with any conditions the Persians might impose in return for the military assistance they were to give. Sultan, however, did not wait for these reinforcements, but early in June, I802, having determined on conducting operations in person, set sail with a formidable fleet of ships and bughlas for Al-Bahrain. Landing in force, he attacked the Attoobees vigorously, but without gaining much success, until two months later, his appeal to Shiraz having been favourably received, a body of 200 horse and 2,000 foot embarked at Bushire to join him. The result of the combined forces acting against the tribe was that the latter were compelled to submit and acknowledge the supremacy of Oman; the aggressive attitude of the Wahabees, at this time, and the consequent necessity of withdrawing a large portion of his army for home defence, alone prevented Sultan from prosecuting the war, until he had completely expelled the Attoobees from the island. His navy, however, had the satisfaction of so far destroying the Attoobee war-craft that by the 
end of October, 1803, their piratical depredations were entirely at an end.

In May, I802, Captain Seton was compelled by ill-health to return to Bombay on twelve months' leave, the Company's native broker being left in charge of affairs until Captain Seton returned to Muscat and resumed charge as Resident in June, 1803.

In I803 the Company's brig Fly, I4 guns, commanded by Lieutenant Mainwaring, was attacked off Kais by the La Fortune, commanded by the famous privateer, Captain Lememe. The despatches and treasure of the Fly were sunk and three of the officers, Mainwaring, Arthurs, and Maitland, were taken to Mauritius. The other officers, having been released, succeeded in recovering the despatches and sailed for Bombay, but were captured on the way by a Joasmee Squadron, which carried them to Julfar. Here they purchased their liberty by giving up the treasure at Kais, and then set out for Bushire, which was reached by two survivors only, Pennel and Jowl, after incredible sufferings and privations, the rest of the party having died on the way. For their great hardships and risks they were unrewarded by the Governor Duncan, who showed great ingratitude and cold-heartedness. The La Fortune soon afterwards also took the Viper, of I4 guns, belonging to the same service. Lememe then proceeded to the Mauritius, but returned to the Gulf early in I804, and committed great havoc until November of that year, when he was himself captured by the English frigate Concorde, which had been sent out in search of him.

In January, I803, Seyyid Sultan resolved on performing a pilgrimage to Mecca, and embarked on board one of his frigates with Shaikh Muhenna al-Yaarebi and others, and set sail for Jedda for that purpose, taking with him presents of money and munitions of war for the Shereef; the regency appointed to act during his absence was composed of his elder son, Salim, his relative, Mohammed Nasir al-Jabry, and Mohammed Khalfan.

Soon after his departure, his nephew, Bedr bin Saif, who was then residing at Hibra, a village near Nakhl, proceeded to Muscat with a few followers and concealed himself in the house of Majid 
bin Khalfan, the brother of the Wali of the town, and endeavoured to seduce the commandant of Fort Jelali from his allegiance. In this intrigue Majid, who was disaffected, lent his aid, but the attempt failed, and Bedr, having been denounced, was barely able to effect his escape. Tradition relates that he was being smuggled into Jelali in a large box, when he was detected by one of the Hindoo traders, who reported the matter to Salim. At all events Bedr got clear off and made his way first to Ajman, from whence he proceeded to Zobara in Katar, and sought protection from the Wahabees, whose tenets he adopted; and with their help he subsequently on two occasions made an attempt on Muscat, but failing in this, he at length determined to make a journey to Nejd, where, in I804, he had an interview with the Amir Saood, who gladly received him.

Some time previous to Sultan's departure from Muscat he had responded to an appeal made to him by the Shereef of Mecca for aid in repelling the Wahabees, who had invaded the Hejaz and were threatening the Holy Cities. The despatch of this force to the Hejaz was an unfortunate move on the part of Sultan, who had reason too soon to repent his magnanimity. Its numerical strength was not only much too small to be of any real service in checking the Wahabee invasion, but when the news of its arrival at Mecca reached the ears of the Amir Abdul Azeez, he became so exasperated at Sultan's action that after his return from the campaign, he declared war against Muscat, and despatched orders to Al-Bahrain, Kwait, and Ras al-Khyma to fit out their fleets to scour the Gulf against Omani commerce. To these orders the Attoobees and Joasmees demurred, as the pearl-fishery season was now commencing and all their men were engaged, so they represented to the Amir that they could not abandon their occupation, but the commands were repeated in so peremptory a manner that the tribes no longer hesitated to obey and the pearl-fishery that year was abandoned in favour of piracy.

The news of the Amir's intention to extend his aggressions by sea as well as by land induced the Persian Government and the Pasha of Baghdad to ally themselves with Sultan against him. vol II. 
In the naval war that followed Sultan personally took an active part and did his utmost to protect his own coasts and commerce from the insults and ravages of the piratical fleet, but his success was not great; his allies had, after some show of assistance, left him in the lurch, and he was now threatened with an invasion by land.

In this critical position Sultan deemed it best to try and propitiate his enemy; he therefore despatched a mission to Deraya and purchased a truce for three years by the payment of a large sum of money, the promise of a yearly tribute of 12,000 dollars, and the establishment of a Wahabee Agent at Muscat. The Amir, however, had no intention of relinquishing his grasp on Oman even on these humiliating terms. He took advantage of the truce to reinforce Al-Harik at Al-Beraimi, and shortly after perfidiously broke it by ordering his general to march. Al-Harik at once poured down into the Batineh, where he committed unspeakable atrocities and easily overpowered the resistance he met with from the disunited tribes in his path.

Sultan had become apprehensive that the suspension of hostilities on the part of Al-Harik was only temporary, and on hearing of Al-Harik's movement, hastily gathered as large a force as he could muster, and a battle took place in Wady Heimali above Sowaik in which the Omanis were routed by the Wahabees. 'This was the first great disaster experienced in Oman at the hands of these fanatics, and Sultan was constrained by the alarm felt everywhere to call a council of war at Burka, to discuss a plan of operations. The Shaikhs of both factions assembled there, agreed to combine against the common enemy, and arranged that each tribe should contribute its quota and assemble at Khaboora on a certain day. Al-Harik, after the affair at Heimali, retired towards Sohar, to which he laid siege, and there quietly awaited the advance of the army of defence Sultan was raising, and which soon numbered 12,000 men. At this juncture the news of the death of the Wahabee's Amir, Abdul Azeez, who had been assassinated at Deraya in October, reached Al-Harik at Sohar, and the advice he then received of affairs at home induced 
him to raise the siege and retire without delay to Al-Beraimi. Relieved from the presence of their exacting masters the Joasmees speedily made peace with Sultan, and the Omanis, unacquainted with the real cause of the sudden disappearance of their foes, ascribed it to their own superiority in numbers or to the success of the negotiations that had been carried on by Sultan with Al-Harik.

Reverting now to events in Europe, we see that when the death of the Emperor Paul dissolved the treaty for the joint Franco-Russian invasion of India overland, Napoleon determined that the substitution of French supremacy for English in India should follow as a natural consequence upon the subjection of England itself, for which purpose he at once began to make preparations. With this scheme before him, Napoleon, towards the close of the year I802, while the Treaty of Amiens was yet in force, selected one of his ablest generals, Decaen, to be the Captain-General of the French possessions in the East, and despatched him with Admiral Linoi's expedition, which sailed from Brest on March 6th, I803.

The mission of General Decaen was to observe closely the position of the English in India in their relation to the native Princes, and to prepare the way for the French conquest and occupation of India, in procuring full information as to the state of affairs and extent of armament required. After visiting Pondicherry, General Decaen fixed upon the Island of Mauritius as his headquarters and post of observation, and on establishing himself there immediately despatched M. de Cavaignac in the Atalanta frigate to his destination. This M. de Cavaignac had been appointed by Napoleon Agent and Consul for France at Muscat, and as his mission had the same object in view as that of General Decaen, to whom he was subordinate, it may be as well to transcribe here the concluding paragraph of the long letter on instructions written for the General's guidance by Napoleon, which indicates clearly enough that the scheme for the conquest of India had not been relinquished, and that Decaen might possibly be -entrusted with the enterprise :- vol. II.

"The mission of the Captain-General is, in the first instance, 
a mission of observation, political and military, but the first Consul well informed by the Captain-General-upon whom he relies for the punctual execution of these instructions-may perhaps place it in his power to acquire a great glory which prolongs the memory of men beyond the duration of ages."

The Atalanta frigate, a famous ship in her day, was painted a bright yellow colour with white mouldings, and was one of the swiftest and handsomest vessels of her class in the French navy. She sailed from Mauritius on September 5th, 1803, and reached Muscat on October 3rd. On anchoring in the cove she was boarded by the Wali, who, on being made acquainted with the purport of M. de Cavaignac's mission, informed that gentleman that Sultan was absent in the interior, being engaged in operations against the Wahabees; he promised, however, that immediate intimation should be sent to him of the Atalanta's arrival, and in the meantime offered M. de Cavaignac the hospitality of a house on shore. At this time the Resident, Captain Seton, was absent on duty, having sailed in the Ternate in the beginning of September for another part of the Gulf, and the French envoy therefore had a fair opportunity of making friends with the leading Arabs, and of pressing the advantages of a French alliance. It was in his favour, also, that the commercial intercourse so long existing with Mauritius had caused the formation of a strong French party in the town, as he was able to depend on the influence of these partisans at the palace, and it was from them that he first learned of the existence of the treaties of 1798 and 1800 .

Congratulating himself, therefore, on the opportune absence of his adversary, the English Resident, M. de Cavaignac entertained for some days high hopes of procuring a favourable reception and of succeeding in his mission. Sultan returned to Muscat on the morning of October 12th, I803. He had been engaged in contending and negotiating with the Wahabee General, but on receiving his Wali's letter, had started at once for Muscat, firmly resolved on the course he would adopt with Napoleon's Agent.

The captain of the Atalanta, on hearing of Sultan's arrival, 
sent two of his officers to convey his respects and compliments, and to ask for an interview. The officers were civilly received, and on being questioned as to the object of the Atalanta's visit, replied that it was desired to establish a French Residency at Muscat, and that an officer appointed to act as Consul by the French Government was on board the vessel. The same afternoon Sultan sent two Arab officials on board with instructions to acquaint the Captain and M. de Cavaignac that His Highness could not receive a French Agent and Consul on account of the engagements recently entered into with the English, and that he declined an interview to discuss the subject, but that, as he wished to remain on friendly terms with the French, his harbours would always be open, as before, to their vessels, and that he would be happy to listen to any proposals they had to make on commercial matters. In dictating this diplomatic message, Sultan was, no doubt, actuated by a keen regard for his country's interests. While fearful of offending the French, the remembrance of Captain Malcolm's arguments and the momentous events that had occurred since his (Malcolm's) visit, such as the evacuation of Egypt by the French army and the triumphs of Lord Lake in India, had created a deep impression on the Prince's mind, and must have convinced him more than ever as to the incomparably greater importance to the Arabs of the English over the French alliance. The tone of the message must have shown M. de Cavaignac the hopelessness of argument and representation on his part, as he does not appear to have again sought an interview, but it was a bitter disappointment to him, for his Arab friends had made him sanguine of success, and he had, doubtless, been anticipating in his mind the approbation of Napoleon. Reluctant, however, to abandon so easily the mission with which he had been charged, he waited in the harbour for one more day, and then, under cover of the darkness of midnight on the $13^{\text {th, the }}$ Atalanta's broad sails bore her out of the port, and by the morning she was nowhere to be seen. This attempt closed for the time French political intercourse with Muscat, and it was not renewed until Saeed sent a mission to the Isle of France after the murder of Bedr in 1807 . But the French privateers, nevertheless, did not cease to make vOL. II. 
Muscat a rendezvous and base for their operations against British shipping in the Persian and Oman Gulfs, and great was the depredation committed by them.

During the ten years of Sultan's reign, from I793 to I804, the loss inflicted on British trade in the Indian Ocean was not less than 250 lakhs of rupees, or about three millions sterling. Sultan and the Muscat merchants had agents at Port Louis specially to purchase English goods and prizes, and many were the ships thus brought to the Gulf or taken to Calcutta for re-sale, for it was not until I 806 that the Marine Insurance Offices in India interfered to check this traffic.

With regard to the proposed alliance between the Pasha and Seyyid Sultan, it does not appear that Sultan's mission to Baghdad resulted in any joint action with the Turks. The Pasha was profuse in his promises of assistance and co-operation, but though equally desirous to see the Wahabees crushed, he preferred to wait and see the Omani Prince exhaust himself in opposing them. Sultan's appeals to the Government of India were similarly unsuccessful ; he was left to bear the brunt of the war alone.

Under a weak ruler, Oman would almost certainly have succumbed to the invader, but Sultan never relaxed his efforts nor spared his resources in the defence of his country, and his indomitable courage and activity infused a spirit of resistance into his countrymen that enabled them for years to keep their foes in check. Until his untimely death in the following year, Sultan seems to have been engaged in an almost continual struggle with Saood's troops, and though he was able to prevent their advance up to the capital, he could never dislodge them from their main post at Al-Beraimi nor expel them from the country.

It was in September, I804, that he left Oman, for the last time, on a naval expedition in the Gulf. He then sailed for the second time to Busra, where he wished to ascertain the extent of the military preparations being made by the Turkish Pasha, in accordance with his promise for operating against the Wahabees. Disappointed and indignant, however, at his reception there, he did not remain long, but turned his face homeward and set sail down the Gulf. 
On his way he transferred himself to an Arab boat or bateel, in order to land at Bassidore, and while in this almost defenceless position was attacked by three piratical dhows belonging to Ras al-Khyma, before any of his fleet could discern his danger or come to his assistance. His assailants were Joasmees, at this time in league with the Wahabees, and, as usual, at war with Muscat, but that they attacked with the set purpose of taking the life of the Omani chief is more than doubtful. Sultan fell at the first onslaught, with several of his attendants ; and the pirates, on finding what they had done, fled at once to escape the vengeance of the Muscat fleet. The various dates mentioned for this event are November 14 th, I 7 th, I8th, and 2oth, I804, but the exact date is not of importance. He is said to have been buried at Lingah.

The news of Sultan's death caused, as may be imagined, intense dismay throughout Oman. Threatened as the country was by external foes the people seemed to be stunned by the loss of their great leader, and for some little time the attitude of all parties was one of expectation. Sultan's death, however, affected not only his own country, it created a great alteration in the state of politics over the whole Gulf. The general consternation at the disappearance of the warrior, who had alone actively opposed the common foe and disturber of public peace, caused every chief to defend himself, not knowing his friends from his enemies, while the Joasmees and Attoobees, being no longer held in check, became more audacious than ever.

Within a month the pirates, whose fleet at this time was very large, captured two English brigs belonging to Mr. Manisty, the Resident at Busra, viz., the Shannon, commanded by Captain Babcock, and the Trimmer, commanded by Captain Cummings, and carried them into Julfar, the Persian name of which about this period was changed to Ras al-Khyma. Part of the crews were put to the sword, and Captains Babcock and Cummings, after being cruelly treated and mutilated, were released. This outrage was followed up a few days later by an attack on the Mornington, a cruiser of 24 guns, by a fleet of forty dhows, which were, however, driven off by a sharp cannonade. 
When starting on the expedition to Busra, in which he lost his life, Sultan had appointed Mohammed bin Nasir bin Mohammed al-Jabry guardian of his two sons, Salim and Saeed, as well as Regent for the conduct of affairs on their behalf.

Mohammed's first impulse was to send Sultan's younger son, Saeed, with four ships and a number of dhows to the Island of Kishm to attack the Jodsmees and avenge his father's death, while a considerable force would proceed to Julfar for the same purpose, but rumours of impending troubles at home prevented the realization of this project.

Kais bin Ahmed, who, as we have seen, had been given the appanage of Sohar by his father, deeming it a fit opportunity for securing the Government for himself, lost no time in collecting the tribes under his influence, and in conjunction with his brother Mohammed marched along the Batineh coast early in 1805 to Muttrah, of which he took possession without difficulty.

In the meanwhile Mohammed bin Nasir, who had summoned some of the Ghafiri tribes to his aid, stood on the defensive, but finding he was unable to retain Muscat against Kais, who daily gathered strength, sued for terms and offered to relinquish Khaboora to Kais and grant him a month's allowance of 2,000 dollars if he would retire. Kais, however, feeling confident of success, refused the terms and continued the siege of Muscat.

After taking council with Sultan's sister Moza and other adherents, Mohammed bin Nasir determined to call in the aid of Bedr bin Saif, who was then absent in Nejd. Bedr appears to have inherited his father's stern and ambitious character, and no sooner had he reached manhood than he began to intrigue against his uncle.

In 1803 while Sultan was absent on pilgrimage, Bedr entered Muscat in disguise and endeavoured by stratagem to get possession of Fort Jelali (as already narrated). He had subsequently proceeded to Al-Deraya, the Wahabee capital, to solicit aid from the Amir in his enterprise against Sultan, and he was returning to Oman with promise ot support when he heard of his uncle's death, and at the 
same time received Mohammed Nasir's invitation to join him at Muscat. The invitation fell in so harmoniously with Bedr's plans that he did not hesitate for a moment, and feeling sure that he could soon get the ascendancy over his cousins, set out at once for Julfar, from whence he proceeded to Muscat. He arrived at a critical time ; Mohammed Nasir and Sultan's sons were on the point of surrendering when Bedr came to their aid and reversed the situation. $\mathrm{He}$ had no sooner learned the position of affairs than he applied for help to his friends the Wahabees, who, in accordance doubtless with instructions from the Amir, were ready and eager to support him, and who immediately dispatched a force to threaten Kais's capital-Soharand thus create a diversion. The plan succeeded; Kais agreed to raise the siege of Muscat on condition of receiving Khaboora, with part of the Batineh, and then hastened home to repel the Wahabees.

A month later Kais found a pretext for renewing hostilities and marched on Muttrah, which he again captured. The approach of large Wahabee reinforcements by sea, said to consist of fifteen dhows and 4,000 men, put an end to the contest, and again compelled Kais to withdraw.

But the Amir Saood, in making this demonstration in favour of Bedr, had no intention of giving his protégé too great an ascendancy. His object was rather to let the two rivals, Bedr and Kais, exhaust their strength in contending with each other, until he could find leisure to establish his own despotism. The Wahabee force, therefore, sailed away again, apparently without landing, and Bedr made peace with Kais on the understanding that Kais should receive Muttrah in addition to his other acquisitions and a subsidy of $\mathrm{I}, 000$ dollars a month.

The Joasmees at this time were very active at sea, and it is recorded that the Company's cruiser Queen was attacked, on April 3oth, by a very large bughla near Muscat on her way up the Gulf. The bughla had ten guns and was strongly manned, but after a severe struggle was beaten off.

The Resident at Muscat, Captain David Seton, was actively engaged at this time in prosecuting measures in conjunction with 
the Muscat Government agaiust the Joasmee pirates for the outrage committed by them in taking the Shannon and Trimmer. Having sailed to the Island of Kishm in the Mornington, he blockaded the Joasmee fleet, until, by the combined operations, the pirates were reduced to seek for peace, and a truce was granted by Captain Seton until he could refer to the Bombay Government on the question of terms. From Kishm Captain Seton appears to have sailed in company with the Minerva, early in June, to Bundar Abbas, where he was joined by Bedr bin Saif with the Muscat fleet.

On the death of Sultan advantage had been taken of the general confusion resulting therefrom, by Moolla Hoossain al-Maeeni, Shaikh of Kishm, to assault and capture Bundar Abbas, which had been leased to the Oman Government some years previously.

In this affair, in which the English ships gave moral support to the allies, but did not fire on the fort, the exertions of the Muscat Arabs were successful in driving out a Kishm garrison and in reestablishing their authority. In return for the support thus afforded, Captain Seton obtained from Bedr bin Saif permission to erect a factory and other concessions.

Bedr bin Saif's return to Muscat in July was hastened, apparently, by the news that his uncle Kais, having broken his engagement, had, in coalition with the Joasmees and Moolla Hoossain of Kishm, left Sohar to attack the capital. By the time Bedr had arrived at Muscat, Kais had already been able to raid the environs unopposed and was preparing to besiege the town. Bedr at once renewed his appeal to the Wahabees to threaten Sohar, while the young Saeed bin Sultan attacked and recovered Bidbid and Fanja in the Semail Valley. The result of the campaign was disastrous to Kais's hopes. He found that he had miscalculated his strength and had no alternative but to purchase peace, by surrendering Muttrah and his subsidy of 2,000 dollars. On the other hand, Bedr had, by his frequent recourse to the Wahabees for military aid against his rival, shown how dependent he was on them for maintaining his position, and how much he had fallen under their influence and tutelage.

The people of Oman beheld with dismay the humiliating and 
increasing submission of Bedr to the dictates of the Wallabec Agent at Muscat, and contrasted his conduct with the patriotic loyalty of their late ruler, Sultan bin Ahmed, who had always done his utmost to check Wahabee pretensions and aggressions, and had not been unsuccessful. In addition to payment of tribute and the maintenance of 400 Wahabee cavalry at Burka to overawe the country, the observance by all ranks of Abdul Wahab's doctrines, with regular attendance at prayers, were strictly enforced, while the minarets of the Ibadhi and Sunni mosques were everywhere broken down and removed.

In this state of affairs the discontent and indignation of the Omanis became daily more widespread and intense, and Bedr, who was looked on as the chief cause of their prostration under the hated invader, became very unpopular.

On July Irth, Captain Skinner arrived at Muscat to take command of the ships in the Gulf to act against the Joasmee pirates. At the end of August, I805, the French ship Belle Poule, of 42 guns and 320 men, a long, low corvette with rakish masts, captured the English ship Endeavour, commanded by Captain Robson, and brought her to Muscat; she afterwards proceeded up the Gulf to Busra.

In October, I805, Moolla Hoossain deputed an Agent to Muscat on behalf of the Joasmees, to continue the negotiations for a peace with the English, which had been commenced at Kishm in June. Captain Seton found that the Joasmees were now more desirous than ever to relinquish pirating English vessels, and he again submitted. proposals to the Bombay Government, which in reply insisted that the treaty should include the whole Gulf, and that full indemnification should be given for all losses. These terms were found quite impracticable by Captain Seton without having recourse to hostilities, but eventually a treaty was entered into with Sultan bin Sakar on February 6th, 1806, by which the Joasmees agreed not to molest English ships in future, and to give three months' notice in the event of their being coerced by the Wahabees into doing so. On the other side, the Joasmees were to be allowed to trade with English ports from Surat to Bengal. 
In the same year (1806) the Joasmees co-operated with Bedr bin Saif in an attack on his uncle Kais at Sohar, and a desultory war followed without much result, as the same year we find Bedr and the Joasmees again at variance, Bedr having sent a secret expedition to Kishm, seized Moolla Hoossain by surprise and brought him to Muscat, where he was held to ransom. In $\mathrm{I} 807$ he was sent back by Mohammed bin Nasir, on his agreeing to hand over Hormuz and Kishm, but in the meantime the Wahabees, exasperated at the news of Bedr's assassination, and eager to strike a blow at the Government at Muscat, threw a force into $\mathrm{Kishm}$, and when the Muscat ships arrived with Moolla Hoossain on board, refused to receive him or to allow the island to be restored. Not content with thwarting Mohammed Nasir at Kishm, the Wahabees despatched a Joasmee fleet of 22 dhows and other vessels to Soor to surprise the fort there, but met with so spirited a resistance on the part of the Jenebeh and Beni $\mathrm{Bu} \mathrm{Ali,} \mathrm{that} \mathrm{the} \mathrm{attack} \mathrm{failed} \mathrm{and} \mathrm{the} \mathrm{Joasmees} \mathrm{were} \mathrm{driven} \mathrm{off} \mathrm{with}$ heavy loss.

Reverting to the year I806, we find that Bedr bin Saif had begun to undermine the rights and claims of his cousins, Salim and Saeed, by excluding them from any share in the government of Muscat. With this view, he had sent Salim as Wali to Mesnaah, and Saeed to Burka, to be out of the way. His designs in all probability were not penetrated by Salim, who seems to have accepted his position contentedly enough, but the more subtle and ambitious Saeed grasped the meaning of his treatment and awaited his opportunity.

At length in 1807 , prompted by these feelings of resentment and urged on, doubtless, by his associates, Saeed resolved to make an effort to recover possession of Muscat and to rid himself and country of one who was now a rival and an enemy. To oppose his cousin in the field, however, was out of the question ; it offered no prospect of success, and no alternative appeared to remain but assassination. Mohammed bin Nasir al-Jabry was the person to whom Saeed naturally turned for aid in the affair, and it was proposed that Mohammed should proceed to Muscat and dispose of Bedr as best he could. Mohammed, however, was fearful of incurring the vengeance 
of the Al-Bu Saeedis, and declined the enterprise, but he did not refuse to assist in arranging the plot that led to the tragedy of Bedr's death.

There are four or five versions of this transaction, but it seems clear that Bedr was enticed to Burka and was attacked by Saeed during an interview at Naaman, a village about four miles distant. Supported by Mohammed Nasir and his guard, Saeed stabbed Bedr, who defended himself bravely and managed to escape from the house and fled towards the Wahabee lines, but was overtaken and slain.

The Wahabee force at Burka was indignant at the murder and demanded the punishment of the offenders, and Saeed was mean and ungrateful enough to throw the blame on Mohammed Nasir. The Wahabees, however, were in danger of being attacked by the excited people and deemed it prudent to quit the country and retire to Beraimi. Saeed immediately set sail for Muscat, sending word of the occurrence to his brother Salim, who had remained quietly at Mesnaah and had not been concerned in the crime. This event, which occurred in March, 1807, was the turning point in Saeed's career, and placed him at once above all competitors. The deed, so far from being reckoned a crime and reprobated, was applauded throughout Oman; Saeed was recognized and acknowledged on all sides as gifted with true Arab courage and instincts, and as one well fitted to hold the reins of power. He was hailed as the deliverer of his country from the hand of one who had turned renegade and had been in league with their invaders. Among the first to approve the deed and acknowledge Saeed's fitness to govern was Kais, who henceforward admitted his supremacy. Saeed was soon joined by Salim, and it was agreed that the two brothers should rule conjointly-an arrangement that was carried out with fraternal affection and without rivalry until Salim's death.

Salim was now eighteen, having been born in 1789 ; he was of a mild and studious disposition and had little energy, but was not wanting in courage and capacity. Saeed was a year younger; his mother was Ghanee, a daughter of Khalfan bin Mohammed al-Wakeel 
al-Bu Saeedi, and besides his having thus a better title by descent than Salim, whose mother was of a different tribe, his high spirits and energetic character indicated him as more peculiarly fitted to take the lead. This he did from the first, as we shall see, and he must be looked on hereafter as the ruling spirit in the government.

The first act of Saeed, who dreaded the vengeance of the Wahabees for the murder of their ally, Seyyid Bedr, was to write to the Amir Saood and exculpate himself from the suspicions that attached to him. He accused Mohammed Nasir of the crime, declared him a rebel, and requested the Wahabees' aid in attacking him. Saeed promised to fulfil all the engagements entered into by Seyyid Bedr as to tribute, etc., to receive again the Wahabee guard of 400 men at Burka, and to observe the Wahabee tenets. This letter, which was accompanied with handsome presents, was despatched by a special messenger. The Amir Saood was not deceived by Saeed's words; he had been fully apprised by his agents at Muscat of the particulars of the transaction, and of the part that Saeed had played in it. Saood, however, to conceal his intentions, wrote a pacific reply, apparently accepting Saeed's excuses and deprecating action against Mohammed Nasir.

The dynastic change and the conduct of Saeed appear to have been viewed with disfavour by the British authorities, and Saeed began to dread lest he should be left alone in the encounter, which he knew was to come with the Wahabees. Saeed, who had been impressed by the Napoleonic wars and successes in Europe, was thus led to turn his attention to the renewal of political relations with the French, which had been relinquished by Sultan, at the request of the British Government.

Since the futile mission of $M$. Cavaignac in the Atalanta frigate in 1803 , the only intercourse had been the occasional purchase by Sultan and Bedr of English prizes, captured and sold at Mauritius by the French. Saeed, determined on seeking French alliance, now despatched Majid bin Khalfan as envoy on a mission to that island to renew the relations which had formerly existed. This mission resulted in a treaty being concluded between Saeed and General 
Decaen, on June 15th, 1807. French influence was now in the ascendant at Muscat for a brief period. In July, 1808 , a fresh treaty with the French was concluded, the first one not having been found satisfactory, and M. Dallons was sent to Muscat as Consular Agent.

By this time the audacity and power of the piratical Joasmees had increased to such an extent that they had become as great a scourge to Oman by sea as the Wahabees were by land, and the trade of Muscat was seriously interrupted. With the object of checking them in some degree, Saeed, in concert with his uncle Kais, undertook an expedition against Khor Fakan, where the Joasmees had formed a piratical station.

In May, I808, Saeed sailed with a flotilla for that fort, where he was joined by Kais, and after a sharp conflict the fort was carried by assault and the garrison put to the sword. News of Saeed's proceedings, however, had been rapidly carried to Ras al-Khyma, which is about twenty miles distant, and Shaikh Sultan hastened to the relief of the place, where he arrived after the massacre of the garrison. He had but a small force with him, yet he easily vanquished Saeed's troops and compelled them to fly, and Kais was killed in the fight.

The troubles of Saeed were now gathering thick upon him, young and inexperienced as he was, for he was now only in his nineteenth year; he would have succumbed before the prospect of carrying on the struggle with such formidable enemies as now surrounded him had he not been sustained by an indomitable spirit of self-reliance.

The Wahabees had now arrived at the zenith of their power; the Amir Saood had determined upon completing the conquest of Oman and had announced his intention of personally leading an army to Muscat, while the system employed hitherto by him in Oman was one of terrorism. He maintained a Political Agent at Muscat and a strong garrison at Beraimi, the frontier town towards Nejd, and it was from this point that his expedition started when hostilities arose in Oman. These excursions were invariably attended by ruthless massacres and barbarities, and the dread they inspired was sufficient 
usually to keep the whole country in a state of abject prostration. In this plight the cup of humiliation for the Omanis was, therefore, nearly full, but they were now threatened with yet greater evils, namely, the complete occupation and direct administration of the land and the effacement of the Ibadhi doctrines in favour of those of their oppressors. Saeed well knew that the Oman tribes had no intention of tamely abandoning their religion, and were ready to respond to any call he might make on them.

At this time, an episode occurred which enraged Saeed's enemies, and gave the Wahabee Amir the pretext he sought for re-opening hostilities. Mohammed Nasir, whom Saeed had denounced to Saood as the murderer of Bedr, and who was now in possession of Semail, was lured to Muscat and treacherously imprisoned. Saeed's object in this was the recovery of the forts of Semail and Bidbid, which he wrested from Mohammed Nasir as the price of his liberty. Bitterly resenting this treatment, Mohammed, who was now as full of animosity towards Saeed as he had formerly been full of loyalty and devotion, made his way to Al-Deraya, where he sought the aid and protection of Saood. The latter had already, as we have seen, contemplated leading a force to act against Muscat, and now adopting Mohammed's cause with alacrity, he despatched his best general, Mutlak al-Mutairy, with the advance of his army to Oman.

In the early part of 1807 the political situation in Europe necessitated orders being sent to Bombay for the despatch of H.M.S. Fox, commanded by Captain Cochrane, with eight Company's cruisers to the Persian Gulf, as a demonstration against Turkey, which had lately declared war against Russia. The frigate, with the Persian Ambassador on board, sailed first to Bushire, and thence proceeded to Kwait, where an interview took place with the Turkish Governor, after which the Fox returned to India.

Enriched by the plunder of peaceful traders the Joasmees at this time greatly augmented their fleet, which, it was calculated, now consisted of 876 vessels, of which 63 were large dhows and bughlas, carrying altogether I9,000 men. In violation of the treaty 
they now re-commenced their attack on English vessels, and even ventured to visit the coasts of Sind, Cutch, and Western India, which they now harassed for the first time.

In April, 1808, the Lively, a schooner, commanded by Lieutenant Macdonald, fell in with four pirates, and after a sharp conflict beat them off. Three of these dhows were soon after discovered at Surat and sent to Bombay, but though found guilty, were most unaccountably released to continue their depredations. About twenty puttimars, or native craft, were, it is said, captured in this cruise by other Joasmee dhows, and on these rich prizes being taken to the Gulf, a further squadron of fifty dhows was despatched to the Indian coast.

We next hear of two of the largest of the Company's cruisers, the Mornington, 24 guns, and the Teignmouth, 18 guns, being successively attacked in the Gulf by these pirates, who were, however, compelled to retire.

Another cruiser, the Fury, 6 guns, commanded by Lieutenant Gowan, was then attempted, as being a small vessel likely to become an easy prey, but the pirates again failed of success. For his conduct and high sense of duty, however, in defending his ship and crew, the commander received unmerited censure at Bombay. A fitting commentary on the above action of the Bombay Government took place a month or two later in the tragedy of the Minerva, a large trading-vessel belonging to Mr. Manisty. This ship was attacked by the Joasmees on her way up to Busra, and after a running fight of several days was carried by boarding. The Minerva was then taken to Ras al-Khyma, where the crew were nearly all massacred one after another in cold blood, the captain being literally chopped to pieces. A lady passenger, the wife of Lieutenant Taylor, afterwards Resident at Baghdad, was detained by the pirates until a heavy ransom had been paid for her release.

In September of this year the mission to Persia of Sir H. I. Brydges, who had been appointed Ambassador, embarked at Bombay on board the La Nereid frigate, 36 guns, commanded by Captain Corbett, with the Sapphire, commanded by Captain Davis, and vol. II. 
Sylph in company. The La Nereid arrived at Bushire on Octuber I4th, but the Sylph, a small vessel of 78 tons, which had Iseen outsailed by the others, was attacked on October 2oth by a llotilla of pirates, who carried her by boarding. The Joasmees, as usual, murdered the crew, twenty-two in number, by cutting their throats over the side of the ship in the name of God, but the captain, Lieutenant Graham, though terribly wounded, managed to hide below. A few hours later, however, the $S y l p h$ was recovered by the La Nereid on her way down the Gulf. Within three days of this event, the Company's cruiser Nautilus, of I4 guns, commanded by Lieutenant Bennett, was menaced off Henjam, by four dhows, which came close up in order to board, but were driven off by a broadside and chased out of sight.

The increased influence of the Wahabees, however, naturally irritated the Joasmee leaders, the chief of whom, Sultan bin Sakar, fell under their displeasure and was carried by force to Nejd. But subsequently escaping to Jedda, he besought the intervention of Ibrahim Pasha, through whose mediation he was entrusted with a mission to Seyyids Salim and Saeed by Mohammed Ali, Viceroy of Egypt, proposing an alliance against the Wahabee Amir. On reaching Muscat, Sultan bin Sakar communicated the proposal to Seyyids Salim and Saced, who flattered by this notice, and willingly adopting it, wrote to Toosoon Pasha, promising co-operation. Putting this offer into action, the Seyyids at once despatched a squadron with Shaikh Sultan bin Sakar on board to Ras al-Khyma, but the object of the enterprise was not accomplished and the squadron returned to Muscat.

In the meantime, Saeed had undertaken an expedition against the Joasmee pirates, and in April, r8og, had set out with a fleet to Ras al-Khyma, to act in conjunction with a force from Bushire. Saeed's allies in the Gulf, however, failed to co-operate, his fleet became dispersed, and he was at one time in a critical situation. With a view to assist the government of Oman at this period orders were sent from Calcutta for the Corniellis and another frigate to be stationed off Cape Mussendom, and many piratical craft were 
captured by them and sent to Bombay, only, however, to te immediately released. Saeed returned to Muscat, unable to boast of any satisfactory achievement.

About May of this year Captain Seton, being required for political service in Sind, relinquished his post at Muscat and returned to India. At this time Major-General John Malcolm, who had proceeded in the brig Psyche on his second mission to Persia under orders from Lord Minto, and who had been entrusted with powers of superintendence over the Company's affairs in the Gulf, concurred with Captain Seton that unless the British Government interfered to save Muscat that port would be destroyed as a port of commerce and the Omanis driven to join the Wahabees and Joasmees, and thus swell the ranks of the enemy.

The height of audacity reached by these Joasmee ruffians, who were as bloodthirsty as they were rapacious, and who within a twelvemonth had attacked no less that eight armed English vessels, had come to be regarded as foreboding the extinction of British trade in the Gulf, and protective measures could no longer be delayed.

That the increase of piracy was due in no small degree to the wavering and infatuated policy of the Bombay Government in tying the hands of its naval officers and in regarding the pirates as innocent and unoffending Arabs-to use the Governor's own words-by which so many lives had been sacrificed and so much valuable property surrendered, is undeniable, as the Joasmees naturally looked upon the action of the English as sheer pusillanimity.

But though this was the main cause of their insolence, other circumstances, doubtless, contributed to their overweening selfconfidence and boldness, such as the configuration of the coast, which was remarkably well suited to aid their operations. At Ras al-Khyma, for instance, there was a commodious backwater behind the town, where dhows could lie in safety far out of reach of gunshot, but more important still, there was Khor al-Shem, a capacious inlet, eight miles in length, the existence of which was absolutely unsuspected by the English at that period. A dark, narrow gorge between black, basaltic rocks, precipitous sides, formed the entrance. vor. II. 
which was invisible outside to those unacquainted with it, and the pirate dhows, when chased, often suddenly vanished by passing into the inlet, leaving their pursuers bewildered at their disappearance; concealed in this obscure and safe retreat, in which no European ship had sailed, and no boat had ventured, the buccaneers could lie in security, ready to sally out and swoop down upon any luckless merchantman descried on the horizon.

The attention of the Supreme Government at Calcutta had long been drawn to the insult to British prestige and commerce in the Arabian Sea, but it was now felt that the policy of inaction had been carried too far and that it was now time to assist the Muscat Government in resisting the Wahabee power and in suppressing piracy.

The Governor-General, Lord Minto, accordingly directed the Bombay Government to prepare an expedition for service in the Gulf. The force assembled for the purpose consisted of the frigate La Chiffone, 36 guns, commanded by Captain Wainwright; the Caroline, frigate, 36 guns; and nine of the Company's cruisers, with several transports carrying the 65th Regiment, under Colonel Lionel Smith, who was in command of the expedition; part of the 47th Regiment, and about a thousand native troops. Captain Seton was appointed to be Political Officer to the expedition, from his great experience and knowledge of the country.

The instructions issued by the Bombay Government to Colonel Smith on September 7 th, 1809 , were of so lukewarm and conflicting a character that the operations of the expedition were rendered practi:ally fruitless, and little or no advantage resulted from them.

The fleet sailed first to Muscat, where the leaders of the force consulted and discussed plans with the rulers of Oman, Seyyids Salim and Saeed. The fleet then moved on to Ras al-Khyma, where it arrived on November Irth. This place was captured and burnt and all its war vessels destroyed. On the expedition returning to Muscat, Salim and Saeed solicited the aid of Colonel Smith against Shinas and Khor Fakan, in co-operation with his own troops. The two forces, accordingly, sailed together, and on January 4th, I8Io., stormed and captured Shinas after a desperate resistance. 
During this campaign Mutlak al-Mutairy, who had been despatched from Nejd with the advance of the Wahabee army, had arrived with Mohammed Nasir at Beraimi, from whence, on hearing of the British expedition, he hastened to the aid of the Joasmees at Ras al-Khyma. Being too late for that affair, he moved across to Shinas, which he reached just after its fall. For three days the small British force awaited the Wahabee onslaught, but Mutlak declined an engagement until Colonel Smith had embarked his troops, when he immediately attacked the Omanis, and with such vigour that he completely routed them.

The position of Salim and Saeed, therefore, now became more precarious than ever, and their powerful enemy, the Wahabees, instead of being dismayed by the English operations, were only exasperated and rendered more vindictive against the rulers and people of Oman.

On the departure of the British, Saeed remained at Sohar which Mutlak, after pillaging the country round and massacring the inhabitants, began to invest. Saeed attempted negotiations, but failed; he was, nevertheless, soon able to compel Mutlak to raise the siege, and the latter then proceeded with Mohammed Nasir to Semail, which very shortly surrendered to him.

Saeed, returning to Muscat, strengthened the forts in the Batineh, still remaining to him; but the Wahabees were expecting reinforcements and were, indeed, already masters of the position. In these straits he was strongly advised by the French Consul, M. Dallons, to compromise with Mutlak, but, trusting in eventual aid from Bombay, Saeed declined this advice.

The Wahabees now raided Oman and harried the inhabitants at will, but Mutlak evidently found their subjugation a tougher task than he anticipated. On the other hand, Saeed's endeavours to rid the country of its foes were unavailing; his utmost efforts were only equal to maintaining his own independence, and when in April of the following year, I8II, Saeed, after repulsing Mutlak from the walls of Muscat, ventured to give him battle in the Maawal Valley, he suffered a disastrous defeat. 
Saeed sent an appealing letter to the Bombay Government in I81o, praying for armed intervention and support against his enemies, representing that his alliance with the British in the late campaign had incensed the Wahabees against him and made them implacable in their enmity. The request, however, was not complied with, as the Government considered it impolitic to undertake hostilities against the Wahabees. Saeed then turned his attention to Persia. It was arranged that his brother Salim should proceed to Fars and request aid from the Governor-General of that province. Provided with suitable presents, Salim accordingly made his way to Shiraz, where the influence of Pishkush procured him the promised assistance of I,500 men. Accompanied by this auxiliary force, under the command of Saadi Khan, Salim returned to Muscat and operations were at once renewed against the Wahabees. In the meantime, Saeed, taking advantage of the Egyptian successes over the Wahabees in Western Arabia, which had compelled the latter to concentrate their forces, despatched his cousin, Hilal bin Hamed, against Zobara and Al-Bahrain. The expedition was partially successful and the Wahabee agent, Abdulla bin Ufeysan, was taken prisoner, but no advantage resulted to Saeed.

The operations undertaken against the Wahabees, on the arrival of the Persian contingent, were conducted by Salim, who, in conjunction with Azzan bin Kais and Saadi Khan, marched against the Wahabees at Nakhl and obliged them to retire to Zikki ; Semail also fell, but unadvisedly pursuing their successes too far, Salim and his Persians were completely routed by Mutlak at Zikki and driven back to Burka. Mutlak took his revenge by raiding and devastating the Sharkiya as far as Ras al-Had, leaving a bloody track behind him.

Towards the end of I8II, the change at Bombay, where a new Governor, Sir Evan Nepean, had been appointed, awakened hopes in the mind of Seyyid Saeed of receiving from India that assistance which he had been long and vainly soliciting, and he determined to send another envoy to Bombay to request that a force of 2,000 troops should be despatched to hold the Wahabees in check and to prevent the occupation of that town and port. The enemy reached Bombay in 
one of the Omani ships in June, I8I2, but was unable to obtiin a favourable reply from the Government, and returned at once to report to the Seyyids the ill-success of his mission. Mr. Bruce, the Resident at Bushire, who happened to be at this time at Bombay, was instructed to call at Muscat on his way back to the Gulf to communicate with the Seyyids on the state of affairs, and to appoint a native agent there on behalf of the Company, who was to act in subordination to the Bushire Residency, which thus from the early part of 1813 was authorized to assume sole charge of Persian Gulf matters.

Before leaving Muscat Mr. Bruce was desired by Seyyid Saeed to accompany him to the Pirate coast and give moral support to the operations he was about to undertake in order to reinstate Shaikh Sultan bin Sakar at Ras al-Khyma, and as Mr. Bruce harl instructions to renew Captain Seton's treaty of $\mathrm{I} 806$, he agreed to do so.

The expedition sailed accordingly, but as Shaikh Shakboot of the Beni Yas, who was expected to join in the affair, failed to give any effective aid, Saeed did not succeed in his enterprise, and returned to Muscat discomfited.

This espousal of Sultan bin Sakar's quarrel and subsequent operations against the Wahabee nominee at Ras al-Khyma naturally gave fresh offence at Al-Deraya, and Mutlak, who had for sorne tıme suspended hostilities and had been residing at Beraimi, received. orders to move against Muscat. He accordingly gathered his forces, quitted Beraimi, and marched along the Batineh as far as Mesnaah. Azzan bin Kais made terms with him en route, and Saeed, unable to offer opposition, arranged a personal interview and induced him to retire, by the payment of 40,000 dollars. With this amount Mutlak returned to Nejd, where his action in abandoning the campaign would appear to have been disapproved of by the Amir Saood. Another general named Al-Azdakah was appointed to succeed him and started for Oman, but was murdered on the way. Mutlak was then again despatched in command with orders to renew hostilities and chastise the Omanis. In the month of November, I8I3, Mutlak set out on his last campaign; he marched through the Al-Dhahireh to Al-Sharkiya, intending to direct his operations against the tribes of vol if. 
this province. He reached, almost unopposed, the country of the Hejrieen, but here he met with a resistance he had hardly looked for, as the tribes had gathered in great force. In the first encounter Mutlak was shot in the breast by a musket ball and fell dead, and the Wahabees immediately fell into disorder, became dispersed, and retreated hastily to Al-Beraimi. Mutlak's arms and coat-of-mail were carried to Muscat, and the dark cloud of Wahabee domination over Oman was scattered, while the hopes of the Wahabee Amir attaining the conquest of Oman were lost. To his able and dashing generalship the success of the Wahabee invasions had been chiefly due, and the Amir had no one of similar capacity to replace him.

Saced's fortunes were now in the ascendant; he had passed through the period of adversity, and his career henceforward, though not marked by uninterrupted success, was brilliant and prosperous. Early in $\mathrm{I} \mathrm{I}_{4}$ the death of Azzan bin Kais at Mokha, in the Red Sea, while returning from pilgrimage, gave Saeed the possession of Sohar, and three months later the death of the Amir Saood from fever at Deraya was a still more decided turn of fortune's wheel in his favour.

The lull in the piratical operations of the Joasmees, caused by Lionel Smith's attack on Ras al-Khyma, was of short duration. Not twelve months had elapsed since its departure before they had reorganized their fleets, recruited their strength, and raised their. heads in maritime supremacy in the Gulf.

Farly in I8ri H.M.S. Lion, 64 guns, commanded by Captain Heathcote, with the Ambassador to Persia, Sir George Ousely, on board, learned that a pirate fleet of twenty-six dhows was cruising off Lingah, and that other vessels from pirate ports were moving about. Their depredations continued to increase and extend more widely, even the Indian and Mekran coasts not being left unmolested by them.

Relieved from foreign pressure, Seyyid Saeed in this year started on a second expedition for the purpose of establishing Shaikh Sultan bin Sakar in his old stronghold, Ras al-Khyma, but the supineness of his allies caused the failure of the chief object of the enterprise, 
but he succeeded in giving Shaikh Sultan possession of Shargah, a town a few miles to the westward, and before quitting the Pirate coast concluded a truce with the Joasmee tribe.

Some Indian vessels navigating under British colours had been pirated off the Kattiawar coast in August, $18 \mathrm{r}_{4}$, and Mr. Bruce called on Hassan bin Rahmah, the Joasmee chief of Ras al-Khyma, for explanations, but the boat by which the letter was sent was seized and the messenger ill-treated. This was followed by the capture of a vessel containing remounts for the $I 7$ th Lancers, and by the seizure of six boats off the Sind Coast.

The Joasmees now, in I8r5, turned their attention to the Red Sea; having raided Hasek and Dhofar and other ports, they began to intercept the trade between India and Mocha, and on one occasion four Surat pattimars, with cargoes valued at twelve lakhs of rupees, were taken and their crews massacred. About the same time the pirates encountered the Muscat frigate Caroline, of 40 guns, commanded by Seyvid Saeed in person, off Kuriyat, and nearly mastered her. His Highness was wounded in the affair and escaped with difficulty.

Shortly afterwards an English merchant ship was taken off Muscat and her crew massacred as usual. This was followed by an attack on the Company's cruiser Aurora, and on the American vessels Persia and Cintra. In 1816 the fortunes of the Joasmees continued to rise. In the beginning of the year Seyyid Saeed conducted a third expedition against Ras al-Khyma and blockaded this port for four months, but without effecting any result.

In September an expedition was despatched from Bombay consisting of H.M.S. Challenger, I 8 guns, and the Company's cruisers Mercury and Vestal, to demand satisfaction for the piracies on the Surat vessels in the Gulf of Aden. Mr. Bruce joined this squadron at Ras al-Khyma in November, but the negotiations entirely failed. Shaikh Hassan not only refused redress, but claimed the right to pirate Indian vessels, saying that if the English were going to protect them there would be nothing left for the Arabs to plunder. 
The Amir Abdulla, who had succeeded his father Saood at Deraya, now appointed a new agent at Muscat, with instructions to adopt a more conciliatory attitude towards the Oman rulers and to endeavour to bring about a permanent peace, the reverses sustained by the Wahabees at the hands of the Egyptians having compelled them to concentrate their strength in Nejd. The Agent's efforts at negotiation at Muscat at first promised success, but the question of Ras al-Khyma proved an insurmountable obstacle, and hostilities recommenced.

For some time after this His Highness's attention was engaged at home in repressing internal disorders in the Nakl district, where Himyar bin Suliman al-Yaarebi, the leading representative of the last dynasty, had, in league with Mohammed Nasir al-Jabry, seized the fort and revolted against Saeed's authority. Saeed attempted to dispossess Himyar, but was defeated in the field; he succeeded eventually by treachery in getting Himyar into his power and putting him to death.

Saeed had no sooner returned from his expedition against Ras al-Khyma, in April, I816, than he projected a campaign against Al-Bahrain, an object on which he had long set his heart. The Muscat armament proceeded to the Gulf in June, and together with His Highness's Persian allies landed on the Island of Arad, but were attacked and routed by the Attoobees with great slaughter, Saeed's younger brother, Hamed, being slain in the fight. The Resident, Mr. Bruce, who had quitted Bahrain in H.M.S. frigate Favourite, commanded by Captain Maud, shortly before the expedition arrived, did his utmost to dissuade Saeed from his enterprise, and offered to mediate and endeavour to make terms of peace, but His Highness declined his assistance, and after suffering defeat, as above stated, and which was due in great measure to the treachery of his allies, sailed away to Congoon to embark a force which had been promised him, to act against the Wahabees. He fortunately discovered in time that he was being led into a snare by the Persians, who intended to carry him a prisoner to Shiraz, and abandoning his project against Bahrain, returned to Oman. 
It was at this time that Mohammed Ali, Viceroy of Egypt, was contemplating the final destruction of the Wahabee Empire, and the Amir Abdulla, foreseeing the coming blow, had need of every available man to aid in the defence of his country, and not only was every Nejdian soldier withdrawn from Oman, but the Arab spirit of clannishness, or perhaps the ingrained hatred of Arab against Turk, induced a large contingent from the Ghafiri or Maaddic tribes of Al-Dhahireh to flock to the standard of the Amir at Deraya.

In September, 1817 , communications were received from the French Governor of Bourbon, proposing a renewal of commercial relations between that island and Muscat, and a favourable reply having been returned by Saeed, a brisk trade sprung up, for the better regulation of which a new convention was signed by Saeed on March 3oth, 1817. This convention appears to have remained in force until the negotiations of the French Commercial Treaty of r844.

During this year (I8I7) and the next Saeed was entirely occupied with intertribal disputes and in contending with his naval enemies, the Joasmees, who attacked and made themselves masters of Khor Fakan. But this was almost their last act of aggression, as the career of Arab piracy was now doomed. It was high time that proper measures were taken against it, for in this year the Joasmees were actively marauding the Indian Coasts and intercepting all trading vessels. They had captured many rich prizes and murdered their crews, some of them within seventy miles of Bombay. It was estimated that the pirates had sixty-four war dhows, besides smaller craft off the Indian Coasts, manned by about 7,00o men and cruisers in squadrons of four to ten. The large dhows were built with high sterns reaching above the bulwarks of a frigate and enabling them to capture large vessels by their favourite method of boarding. Many of them were provided with a long gun on the upper deck traversing in every direction, and thus became, with their strong complement of men, very formidable opponents.

After six years of warfare Mohammed Ali had entrusted his son, Ibrahim Pasha, with the task of subduing the Wahabees by seizing 
their capital. During the year $18 \mathrm{r} 7$ Ibrahim toiled across the Arabian desert, and in April, 1818, began the siege of Deraya, which was captured and razed to the ground in September, when the victorious General returned to the Red Sea. The overthrow of these fanatical puritans, by whom the Joasmees had been so long and persistently supported and controlled, gave the Indian Government the opportunity for which they had so long waited, of striking a mortal blow at them and putting an end once and for ever to the insults and depredations to which commerce had been subjected for so many years; and a naval and military expedition for the reduction of Ras al-Khyma and the consequent annihilation of the piratical fleets was resolved on. Previously, however, to the despatch of the force, it was deemed advisable to send an envoy to confer with the Oman Government on the subject, and to push on to Nejd to propose to Ibrahim Pasha that the English and Turkish troops should act conjointly in attacking the Joasmee stronghold. Captain Sadler, who had been selected for the mission, arrived at Muscat on May 7 th, I8I9, in the Thetis, I4 guns, and was well received by Seyyid Saeed, who promised to co-operate by land and sea, but declined to join the field with the Turks, whom he detested as much as he did the Wahabees. Captain Sadler then proceeded to Kateef, and traversed Nejd to meet Ibrahim Pasha, whose camp he reached near Medina in September, I8r9. The mission proved abortive, as it had started too late, and Mohammed Ali, having already accomplished his object, refused any participation in the Indian Government's enterprise.

The expedition, now organized at Bombay under the command of Sir W. Grant Keir, consisted of the Liverpool, 50 guns. commanded by Captain Collier; the Eden, 26 guns, commanded by Captain Loch; the Curlew, and six Company's cruisers, together with a land force of $r, 600$ European and r,400 native troops embarked in transports.

The fleet sailed from Bombay in November, I8I9, and rendezvoused at Kishm, but the General, Sir W. G. Keir, proceeded to Muscat, where H.H. Seyyid Saeed agreed to furnish three ships and 4,000 men and to accompany the expedition himself. Early 
in December, after a short bombardment, the troops were disembarked, Ras al-Khyma was taken and the ports destroyed. The town was found to be empty, as the Arabs had removed everything. Shaikh Hassan and his tribe then submitted to the General. About eighty vessels, large and small, fell into the hands of the force, but the greater number escaped capture, having probably sought concealment in Khor al-Shem.

The General having arranged by treaty with Shaikh Hassan bin Rahmah, Shaikh Sultan bin Sakar, Shaikh Shakboot, and the Chief of Debaye for the good order and tranquillity of the Gulf, sailed in H.M.S. Liverpool for Bombay in March, 1820, but to ensure the observance of the treaty, Ras al-Khyma remained in the occupation of the English until the following July.

After the reduction of Ras al-Khyma piracy for some years remained in abeyance, but much vigilance and care were required to prevent the tribes on the Arab littoral from again resorting to their former practices, as the jealousy between them, and pugnacity towards each other, were so great that they were constantly in collision, and it may be as well to record here the few instances of piracy that took place in following years, until it was quite extinguished.

In 1824 a vessel belonging to Al-Bahrain was pirated by two boats from Shargah, with the connivance of Sultan bin Sakar, but the Commodore in the Gulf, on hearing of it, demanded and obtained full satisfaction.

In 1828 a piracy was committed off Sohar by the Joasmees, who massacred the crew, fourteen in number, of the captured vessel. The aggressor in this case, Muslim bin Rashid, was put to death and the cargo recovered.

In I84 $\mathrm{I}$ another outrage occurred off Bidda and Commodore Brucks proceeded thither to obtain redress, but it was not until Bidda was bombarded that the pirates submitted and complied with demands.

In I845 one Hamaid bin Majdal established himself on an island and commenced piracy on his own account with three dhows. but he was soon after attacked by Commodore Hawkins in the 
Coote and reduced to submission. Nine years later Hamaid bin Majdal, having gathered 2,000 men near liateef, renewed his piratical depredations, but Commodore Robinson operated against him with gunboats, and after much trouble succeeded in seizing his vessel and scattering the band.

A few months later a joint expedition was undertaken by the English and by Saeed against the Beni Bu Ali tribe in Jaalan, the immediate cause of which, so far as the British were concerned, was the murder of the interpreter of the Mercury brig which had been despatched to Al-Askhara to enquire into certain piratical acts committed by the tribe. Part of the force, stationed by Sir W. G. Keir in the Gulf, consisting of six companies of Native Infantry and six guns, was now embarked by the Political Agent, Captain Thompson, who had resolved on immediate hostilities, and taken from Kishm to Muscat.

Saeed had for some years been at variance with the Beni Bu Ali tribe, on account of their having coalesced with the Wahabees and adopted their tenets in $18 \mathrm{II}$, and he had since been seeking for an opportunity to crush them. The expedition was undoubtedly due in part to Saeed's instigation and encouragement, and he had been allowed to join it with about I,000 men. Captain Thompson sailed from Muscat to Soor and the combined force marched from that port to the Beni $\mathrm{Bu}$ Ali country on November Ist, I820. The tribes were summoned to surrender, practically unconditionally, by Saeed, but refused to give up their arms, and a contest ensued in which the British force was completely defeated with a loss of six officers, 270 men, and all the guns. The survivors retreated by way of Al-Sharkiya and Oman, through the Wady Akk to Muscat, where they arrived on November I7th. Saeed displayed great gallantry and coolness throughout the affair, and was wounded while endeavouring to save a British soldier. In acknowledgment of his services a sword of honour was presented to him by the Governor-General, who in I82I despatched Dr. Jukes to Muscat to deliver it.

To retrieve this disaster a large force was despatched, under General Sir Lionel Smith, from Bombay in January, 1821. The 
General attacked the Beni Bu Ali in March, and after severe fighting, destroyed the forts and almost annihilated the tribe, which to this day has never recovered its former strength and prestige. Saeed was not permitted to take part in this campaign, though he personally accompanied the troops. It was during his absence from Muscat on this occasion that he had to mourn the death of his elder brother Salim, who died of paralysis in February, I82I. A large number of prisoners of the Beni Bu Ali were carried to Bombay by General Smith, where they were detained for about two years, when they were released and sent back to Oman with a sufficient sum to enable them to rebuild their houses and aqueducts.

It was subsequent to, and to some extent in connection with, the expedition under Sir W. G. Keir that the Survey of the Persian Gulf and Oman coasts was undertaken by the Court of Directors, who had at length begun to understand the necessity of acquiring information regarding the navigation of these seas. In 1820 the ship Discovery and the brig Psyche, commanded by Captains Morgan and Guy respectively, were sent from Bombay with orders to commence the survey along the western side of Cape Mussendom and the Pirate coast, and it was at the very outset of their operations that the remarkable creek, Khor al-Shem, which had been of such importance to the pirates as a hidden port, was discovered. It was named by the surveyors Elphinstone Inlet, after Mr. Mountstuart Elphinstone, then Governor of Bombay. Captain Morgan soon retired from ill-health, and was succeeded by Captain Guy; this officer shortly afterwards gave place to Captain Brucks, who continued to conduct the survey of the Gulf until its completion. In I828-9 the Discovery, with the schooner Inspector, began the survey of the Oman coast from the Eastern side of Cape Mussendom from Malcolm's Inlet to Lima, Dibba, Khor Fakan to Sohar, and thence along the Batineh coast to Muscat and Muttrah, which were first surveyed in 1828. The Discovery, proving unseaworthy, had been replaced very early in this work by the Benares, commanded by Captain Haines, who subsequently surveyed the South Arabian coast as far as Aden. 
In I822 Captain F. Moresby, R.N., in His Majesty's ship Menai, was ordered to Muscat to conclude a treaty with Saeed for the suppression of the slave trade. Saeed granted all concessions asked for, which would, if strictly enforced, have caused him a loss of $£ 5,000$ or $£ 6,000$ a year.

Relieved from all troubles, foreign and domestic, and feeling that he had securely consolidated his power, Saeed now undertook a pilgrimage to Mecca. He appointed his nephew, Mohammed bin Salim, Regent during his absence, and sailed in the Liverpool, 74 guns, which had been specially prepared for the voyage in Bombay, in March, 1824. This journey was performed with great lavishness of expenditure. The Pasha of Egypt, Mohammed Ali, sent officers to meet him, and nothing was omitted by them and the Turkish Governor to give Saeed a fitting reception on his arrival at Jedda. On the way to Mecca and Medina he was accompanied by a large escort and entertained with great sumptuousness. He created everywhere an immense sensation, and his popularity among the people was not lessened by the generosity of his gifts. Notwithstanding his being a Kharejite or dissenter, Saeed was received with the greatest respect and honour by the Shereef, and on his departure was presented with splendid gifts by Mohammed Ali. Saeed was received on his return to Muscat with. loud acclamations, and the rejoicings lasted several days.

In July, I826, Saeed sent a fleet to blockade Bushire in the absence of the Governor, Shaikh Abdul Russool, though at the request of the Resident, he refrained from attacking the town. The Shaikh himself was captured at sea on his way home shortly after, and detained a prisoner until the following year, when he paid a ransom of 80,000 dollars and agreed to surrender a Persian princess, a granddaughter of Fath Ali Shah and a sister of Reza Kola Mirza, who had been promised to Saeed, but had been delayed at Bushire by the Governor, who was desirous of marrying her himself. In November of the same year, Saeed, having been unable to prevail on the Goveriment of Busra to pay the stipulated subsidy, the arrears of which had amounted to I04,00, dollars. equipped a fleet to enforce 


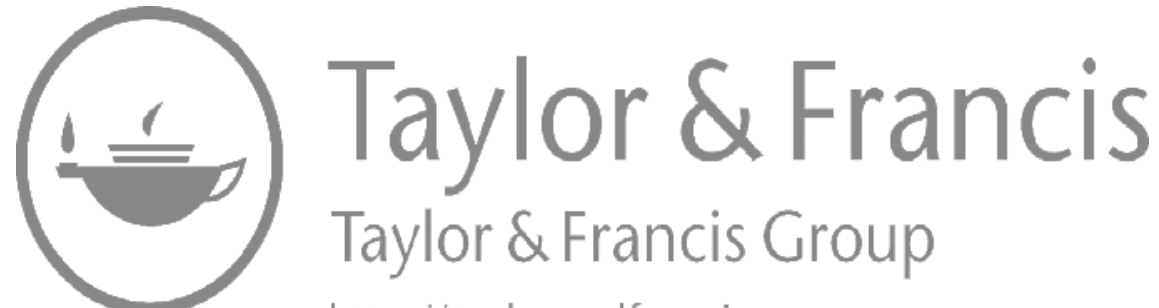
http://taylorandfrancis.com 

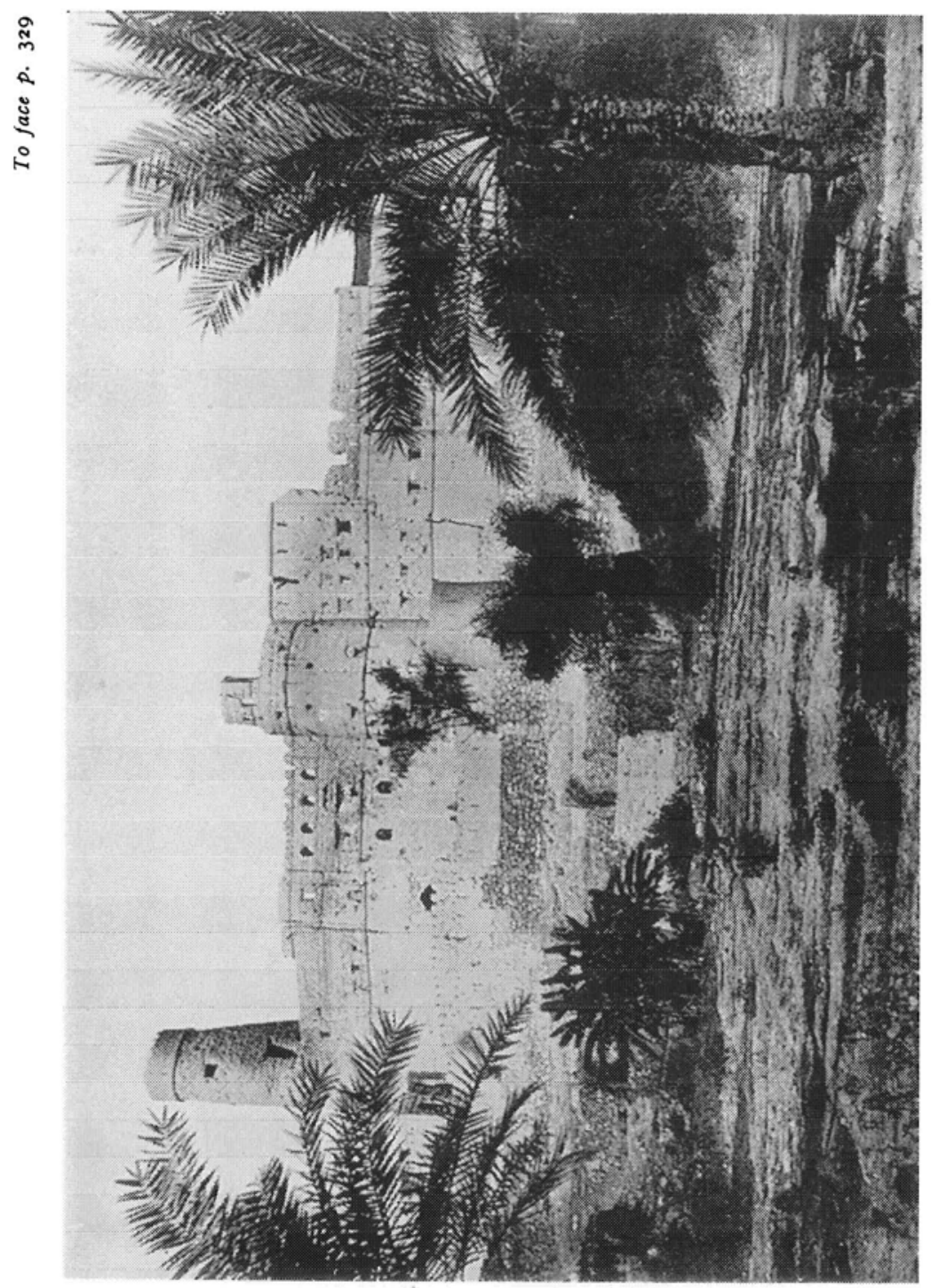

ถึ้

a.

ตั้

过

4

봉

昌

紱 
his demand. In an engagement that ensued the Turkish fleet was defeated and Busra was blockaded until the Pasha made terms.

The following year was spent by Saeed in a fruitless war with Al-Bahrain, for which he had made long and expensive preparations. With the object of taking the Attoobees by surprise, Saeed contradicted the rumours prevalent of his intentions and assured the Shaikh of his pacific feelings, until about a month before his arrival there with his fleet, which was in November, 1828 . In his attack on the island, however, his force was completely routed and many slain, while he himself was slightly wounded. Being thus discouraged in his enterprise, he abandoned its further prosecution and returned to Muscat. A peace was concluded between the belligerents on terms not unfavourable to Saeed in December of the following year.

In 1829 the Chief of Dhofar, Mohammed Akil, was murdered at Merbat, and Saeed immediately despatched a force to take possession of that district. This force only remained a few months, as it was required for service in East Africa, whither Saeed was about to proceed with the object of subduing the district and island of Mombasa. Having arbitrarily seized and imprisoned his cousin, Hilal bin Hamed, with a view to prevent his intrigues with the tribes, and leaving Mohammed bin Salim in charge of the Government, he sailed on December I5th, 1829, for his East African dominions, which were to occupy his chief attention for the next fifteen years.

The first occasion in which Saeed had interfered in Zanzibar territory had been in $18 \mathrm{r} 2$, when he sent a Wali named Khalaf bin Nasir, and built a fort at Lamoo. Ahmed bin Mohammed died in I8I4, and was succeeded by his son Abdulla, a brave and enterprising chief, who, resolving to separate from the mother country, refused to send any tribute to Muscat. Being conscious, however, that this course would inevitably lead to a contest, Abdulla sailed to Bombay and endeavoured to secure the alliance of the Indian Government.

Some time later internecine broils at Patta, the suzerainty over which was claimed by the Wali of Mombasa, compelled one of the parties to call in the aid of Saeed. A small force, under Abdulla Ali, was sent from Muscat, which established Bwana Shaikh as Saeed's vol. II. 
vassal. The Wali of Mombasa, however, soon recovered his predominating influence, and matters so remained until fresh dissensions arose, when Saeed again invited him to interfere, and, burning with jealousy against the Mezeri Chief, sent a second expedition in 1822 under Hamed bin Ahmed, who received the submission of Brava, Patta, and Siwi, while Saeed's Wali at Zanzibar, hearing of Ahmed's proceedings, seconded him by attacking Pemba and expelling the Mombasa garrison.

Abdulla bin Ahmed died in 1823, and, as the succession was disputed, the people elected Suliman bin Ali, the ex-Wali of Pemba, to act as Regent tempcrarily. Saeed was at this time getting ready another fleet at Muscat, and had issued orders that his people were not to trade with Mombasa, a measure which, in connection with the recent loss of Pemba, the source of its food supply, did much to weaken Suliman's position. Apprehensive of the result of a contest with Muscat, Suliman bin Ali had written to the Government of Bombay soliciting protection, but no answer was received to this appeal.

It happened, however, that on the 3rd December, I823, the ten-gun brig Barracouta, which had left England in 1822 in concert with the frigate Leven, 28 guns, commanded by Captain Owen, who had been commissioned to survey the coasts of East Africa and Madagascar, sailed into port. Taking advantage of the opportunity, Suliman immediately sent his nephew on board to explain the position of affairs and to request Captain Vidal's permission to hoist the British flag and to place the town and fort in the hands of the King of England, in order to avoid its subjugation by the ruler of Muscat. Captain Vidal, who was indisposed, took time to consider his reply, and the next day sent Lieutenant Boteler on shore to inform the Wali Suliman that he declined to accord British protection to Mombasa, but would be happy to forward any letters on the subject from the Wali to the Government of Bombay or the Cape of Good Hope.

The Barracouta sailed from Mombasa on December 7 th, and a few days later the Muscat flotilla, commanded by Abdulla bin Snleyyim, arrived in port. On sighting the fleet, the Wali Suliman, notwithstanding Captain Vidal's refusal to comply with his request, 
had hoisted the British flag, hoping thereby to deter Abdulla bin Suleyyim from commencing hostilities. The ruse, however, completely failed, and the blockade had continued for two months when. on February 7 th, 1824, the frigate Leven anchored in the harbour. A similar application was immediately made for protection by the Wali to Captain Owen, who, taking a different view from that of his subordinate, Captain Vidal, agreed to a convention, accepting the sovereignty over Mombasa from Melinda to Pangani, on the part of England, on ccndition of the abolition of slavery. The Arab ccmmander, Abdulla bin Suleyyim, at once placed himself under the orders of Captain Owen, and agreed to give up the blockade. Captain Owen appointed one of his officers, Lieutenant Reitz, as Governor, with a midshipman, Mr. Phillips, and four men as guard, and sailed on February $13^{\text {th }}$ for Pemba and Zanzibar, where the Governor, however, Saeed Mohammed al-Akhabari, refused to surrender Pemba, which had been a dependency of Mombasa previous to present hostilities.

In September following, the Andromache, commanded by Commodore Nourse, arrived at Mombasa, and appointed Lieutenant Emery as Governor in the place of Lieutenant Reitz, who had died of fever on May 29th.

Captain Owen revisited Mombasa on November 2nd, 1824, and on December and the Leven and Barracouta sailed again to continue the survey, after according to Brava British protection on similar terms, and Captain Owen made an arrangement with the Wali of Zanzibar that no interference should take place on the Wali's part with the East African coasts until the decision of the Government became known.

In 1826 Suliman bin Ali was deposed by Salim, the brother of the late Wali Abdulla bin Ahmed; Lieutenant Emery, the Governor at Mombasa, not interfering in the matter. It was not until two years after Captain Owen had agreed to the protectorate that the English Cabinet, at the instance of the Indian Government, disavowed Captain Owen's proceedings, and the British commandant was removed from Mombasa, which was left with Pemba and Brava to settle its own quarrel with Saeed. Saeed lost no time in writing vor. Ir. 
to Salim and summoning him to surrender. Salim in reply offered to acknowledge a nominal sway and to remit a tributc, but refused to yield the fort. This did not satisfy Saeed, who, however, was too much engrossed in home affairs to be able to pay much attention to Mombasa, and it was not until r829 that, having completed his preparations, he sailed in the Liverpool with a large fleet and I,200 men from Muscat, expectant of an easy victory. The sight of this imposing force riding at anchor before his little island did not terrify Salim; he refused defiantly Saeed's demand for submission, and declined to accept his invitation to an interview, stating he was prepared for defence. A general assault was then made by Saeed. but it was repulsed with heavy loss, and after several ineffectual attempts Saeed deemed it prudent to raise the siege and to retire to Zanzibar.

In the meantime serious disorders were taking place in Oman, Incensed at her brother's imprisonment, Jokha, the sister of Hilal, seized the fort of Sowaik and razed the Batineh. Hamed also joined in the insurrection, made himself master of Sohar, Khaboora and Shinas, and prepared to march on Muscat. Mohammed bin Salim, seriously alarmed, sent a vessel to recall Saeed from Zanzibar, and appealed to Bombay for help. Two cruisers were ordered to support him and to prevent an attack being made on Muscat. The Resident of Bushire, Captain Hennell, also kept other vessels ready and warned Hamed not to attempt an attack. Saeed returned to Oman in May, 1830 , and pretended to think that the rebellion had been of an insignificant character, and that he had been recalled without reason. Nevertheless, he was unable to recover either Sohar or Khaboora from Hamed, and had to content himself with the restitution of Shinas. In an expedition against Sohar, in February, I83I, undertaken by Saeed, he was disastrously defeated by Hamed, with a loss of 400 or 500 men, and had to retreat with his finances and reputation reduced to a very low ebb.

Early in the next year, Saeed set out on a fresh expedition to East Africa in the Liverpool, with the intention of again besieging Mombasa, but this time he deemed it advisable to strengthen the 
Regency, which was to rule Oman in his absence, by associating his eldest son Hilal and Saood bin Ali of Burka with Mohammed bin Salim. Saeed's force consisted of 1,400 men in four ships and six bughlas, and, having on arrival spent three days in fruitless negotiations, commenced to bombard the town and forts. This proved unavailing and overtures were again resorted to. Salim bin Ahmed, on receiving hostages, came on board the Liverpool and a convention was concluded to the effect that Salim should recognize Saeed's sovereignty, and should continue to hold the governorship of Mombasa as hereditary in his family, that he should also hold and reside in the fort, which was, however, to be garrisoned by fifty men appointed by Saeed, and that the customs should be equally divided between His Highness and Salim. Saeed then entered and formally took possession of the fort, and appointed Saeed bin Khalfan as Akeed or Commandant. Instead of fifty, however, Saeed introduced a garrison of 200 men, and then ordered Salim to quit the fort and reside in the town. Before leaving, His Highness repaired the for and stationed a garrison of 350 men, Belooches and Arabs, in it, and then set sail for Zanzibar.

Saeed appears to have already resolved to fix his residence at Zanzibar, for he began to build a palace at Mentony, and to lav out clove and rice plantations. But he was not destined to enjoy tranquillity long, for he had, in fact, no sooner left Muscat than disturbances of a serious character broke out, and the integrity of his dominions was threatened; these disturbances were due chiefly to harem intrigues and to the existing jealousy between Saood bin Ali and Mohammed bin Salim.

Taking advantage of the arrival of Hilal and Mohammed at Burka, whither they had proceeded en route to Rostak, which had been made over to Hilal, Saood seized and imprisoned both of them and then laid siege to Mesnaah. Hamed bin Azzan, Hilal bin Mohammed, and Sultan bin Sakar, also took up arms, the last seizing Khor Fakan and Dibba, and the two former beleaguering Rostak. The Moza took the lead on behalf of Seyyid Saeed, and was joined by Talib and Mohammed Nasir al-Jabry, with 1,500 vol. II.

E 3 
Ghafiris, at Muscat, while the Beni Naeem, at their request, made a diversion against Sohar. To support Saeed's rule the Resident at Bushire wrote a warning letter to the insurgents, and despatched his assistant with a naval force to Muscat, but in the meantime Saood had released his prisoners on payment of 8,000 dollars, and on the arrival of the Assistant-Resident at Burka, Saood withdrew his pretensions and exculpated himself by saying that he had only acted in self-defence.

The quelling of this rebellion and the restoration of tranquillity was attributed solely to the prompt support afforded to Saeed's authority by the British Government, which encouraged and brought forward His Highness's friends, while it effectually checked and dismayed the insurgents.

Saeed returned from Zanzibar on September Ioth, 1832, and after appointing Saood to Rostak, on condition of his giving up Burka, solicited aid in recovering Khor Fakan and Dibba, but this was refused by the Government, and he was advised to remain at home in future and protect his Arabian dominions. Saeed, when starting from Zanzibar, had ordered Hamed bin Ahmed, the Wali of Zanzibar; to reduce Magdesho with the Mombasa fleet; Hamed bombarded Magdesho, which submitted, and his sailors sacked the town. Abdulla bin Suleyyim was killed on this occasion. His old foes, the Wahabees, had by this time again turned their attention towards Oman, and their attitude caused Saeed much anxiety. He was not in a position to offer any effectual resistance to their encroachments, and, under the advice of the British authorities, deemed it his best policy to enter into friendly relations with them. He accordingly agreed to pay them an annual subsidy of 5,000 dollars on condition of the integrity of his dominions being respected ; a stipulation was also made that each party should assist the other in quelling rebellions in their respective countries, but this latter engagement was considered impolitic and was disapproved of by the British, as leading to possible embarrassments.

The arrival at Muscat at this time of the United States sloop of war Peacock, with Mr. Roberts, who had been appointed 
Plenipotentiary to negotiate a treaty of amity and commerce with the kingdom of Oman, was a notable event in the life of Saeed. The growing importance of Muscat and Zanzibar as commercial depôts had begun to attract foreign merchants, and improvements in the Customs regulations soon became a necessity. The chief part of the trade and customs farm was still, as it had been for centuries, in the hands of Indian traders, whose position was well known and assured, and in whose favour no cause had arisen for England to interfere. The American merchants, however, were in a different position; they had only begun to trade with Zanzibar some ten or twelve years previously, and had already suffered so much from the exactions and obstructions to which they had been subjected by the Farmer of Customs. They compelled them to make representations to their Government, which thus took the lead in entering into engagements with Oman to remove grievances and place its commerce on a secure and satisfactory basis.

The treaty, which was concluded in September, 1833, was of a comprehensive character and well considered in its details, and formed the prototype on which the English and French treaties were subsequently drafted. Saeed's engagements with foreign powers had heretofore been confined to conventions with British India and French colonies, and it was with unconcealed pride and gratification that he now for the first time found himself placed on a level with the rulers of civilized states, and, though the capitulations he had bound himself to observe complicated his former relations, the treaty, as he probably foresaw and understood, had the effect of raising his position and increasing the trade and prosperity of his country.

It was not in accordance with Saeed's character that he should allow the opportunity to slip without intriguing to gain some advantage for himself, and as the conquest of Mombasa was the matter now uppermost in his mind, he offered to allow the Americans to erect factories where they pleased, at Zanzibar or on the East African coast, on condition of their rendering him armed assistance in the prosecution of his plans. It does not appear that the United States Government reciprocated Saeed's views, nor is it likely they would have voL. II. 
consented to engage in such an enterprise, but the news of the proposal was received in India with the reverse of pleasure, and His Majesty's ship Imogene was soon despatched to observe the state of affairs. Captain Hart reached Zanzibar in 1834 and was able not only to frustrate the proposed scheme but to obtain Saeed's consent to the negotiation of a similar treaty with England.

To return to Africa: Saeed had no sooner quitted Zanzibar in August, 1832, than a rupture broke out at Mombasa, the result of which was the restoration of Mezini independence. Saeed had instructed the Wali of Pemba, Nasir bin Sultan al-Meskeri, a bitter enemy of the Mezini, to proceed to Mombasa and assume the Waliship from Salim. In this demand he was supported by the commandant of the garrison, for whom he had probably brought written orders. Salim, however, refused to submit to this violation of the treaty, and ordered Nasir to quit the place in twenty-four hours. Nasir then shut himself up in the fort, and commenced to bombard the town, which had no means of replying. The whole population, however, siding with Salim, blockaded the fort, and cut off the supplies, and the garrison, being at length reduced to extremities, were compelled to capitulate after a siege of seven months. The commandant and his men were allowed to leave Mombasa unmolested, but Nasir was detained and kept in irons. An abortive attempt to relieve the place was made by Saeed, who sent Hamed bin Ahmed in the Shah Allum to assist Nasir, but he arrived too late.

It was not until about November, 1833, that Saeed, having arranged terms with the Wahabee General, Saeed bin Mutlak, was able to devote his energies to the re-conquest of Mombasa. Having appointed his third son, Thowaini, his deputy at Muscat, His Highness set sail in the Ruhmanee, with the Liverpool, 74 guns, two corvettes, and I,400 men, and anchored off Mombasa Fort. Salim and the Mezinis, fearing the vengeance of Nasir, should the latter ever gain power over them, strangled him in prison, and Saeed, enraged at this action, immediately commenced a bombardment. His attacks, however, were repulsed by the Mezinis, who captured and destroyed two bughlas, and Saeed, after eight days' ineffectual war- 
fare, had recourse to negotiations. Saeed pretended to regret his precipitate hostilities, and proposed peace on the basis of the last treaty. This was accepted by Salim, who agreed to acknowledge Saeed's sovereignty, but made proviso that the citadel was not to be occupied by Saeed's men. Saeed induced two of Salim's relaticns to accompany him, and with this appearance of victory he proceeded to Zanzibar in triumph.

Almost from the time of his first stay in Zanzibar, Seyyid Saeed had been in correspondence with Radama II., King of Madagascar, and about six years after the death of that great ruler in $1828, \mathrm{His}$ Highness sent an envoy in the frigate Piedmontese to Ranavolana Manjaka, Radama's widow and successor, to request her hand in marriage. His matrimonial proposals were slighted by the Queen, who does not appear to have treated the ambassadors with particular distinction; she offered him, however, a young princess as wife instead of herself.

Soon after, Saeed sent an expedition against Siwi, which had revolted. Salim assisted the people of Siwi, and Saeed was defeated with immense loss. At Patta and Siwi, again, further aggressive movements were equally unsuccessful.

Saeed's stay at Zanzibar was again of short duration, his ambitious schemes had no sooner led him to distant shores than internecine troubles at home recalled him to restore order. The breaker of the peace on this occasion was Hamed bin Azzan, who, taking advantage of the murder of Saood bin Ali by his cousin, Sultan bin Ahmed, marched on Rostak and took it, and then prepared to attack Semail, the Wali of which, Mohammed Nasir al-Jabry, had lately died. It was feared that Hamed, by the acquisition of these forts, might be in a position to overawe and seize Muscat, and the British Resident, in July, I834, with a view to support Saeed's government and authority, moved down to Muscat and informed Hamed that his persistence in rebellion would lead to his being considered an enemy of the British Government. This intervention was effective in checking Hamed's designs for a time, but a few months later his irrepressible ambition prompted him to take up arms again and seize Sowaik, from which 
fort, however, he was very quickly dislodged by a force despatched from Muscat. Hamed's popularity in the country, nevertheless, continued to increase, and although Thowaini called in the Joasmees and the Beni Yas tribes to his aid, he was able to effect nothing against his cousin until the return of Saeed from Zanzibar in April, 1835. Saeed immediately took the field and proceeded against Sohar, but although this expedition returned with only a bare semblance of success, his presence at home was sufficient to re-establish his authority and put an end to Hamed's hostilities.

It was in November, I835, that Lieutenant Wellsted, of the Indian Navy, the pioneer and foremost explorer of Oman, arrived at Muscat in the schooner Cyrene. To his pen we are indebted not only for the best description of Eastern Arabia, but the first correct map of the country, taken from personal notes and scientific observations. Lieutenant Wellsted spent several months in traversing the various provinces, receiving every aid and protection from His Highness Seyyid Saeed.

The famous experimental voyage to test the navigability of the River Euphrates as an alternative route to the Red Sea was carried out by Colonel Chesney with two steamers built for the purpose at Laird's. The expedition started from Bir, on the Euphrates, in March, 1836, and the surviving steamer Euphrates (the Tigris having been lost on the way) arrived at the Persian Gulf in June. Colonel Chesney, having completed his work, left for Bombay in the following November in the steamer Hugh Lindsay. It may here be noted that it was in this vessel, the Hugh Lindsay, of 4II tons, that Captain John Wilson had, six years before, performed the remarkable feat of steaming to Suez from Bombay in thirty-two days and had subsequently performed the same voyage on several occasions. In visiting Busra this year he thus became the pioneer of steam navigation in the Persian Gulf as he had been in the Red Sea. One of the medical officers attached to Colonel Chesney's expedition was Dr. Helfer, who, with his wife, on arrival at Bushire, embarked on board the George Bentinck, and on the way to Calcutta touched at Muscat, where Madame Helfer took the opportunity of visiting His Highness's 
harem, of which, as well as of the town, she gives a graphic description in her Travels.

Affairs in Oman for some time occupied Saeed's attention, but, although pining to return to Zanzibar, he was fearful to leave Muscat while Hamed was unsubdued, as the latter would be certain to take advantage of his absence. His Highness, therefore, in 1836 , entered into an arrangement with Saeed bin Mutlak to unite in expelling Hamed from Sohar and Rostak. Saeed bin Mutlak accordingly besieged Sohar by land with 2,000 men, while the Muscat fleet blockaded it by sea. Hamed's position was getting desperate, when he succeeded in rousing His Highness's suspicions as to the intentions of the Wahabees, and operations having been abandoned, the fleet returned to Muscat. Soon after this a vessel of the' Indian Navy, under instructions from the Government, who were desirous of promoting a reconciliation between Saeed and Hamed, proceeded to Sohar, and having received Hamed on board returned to Muscat, where a written engagement was entered into by the latter that he would not again rebel against Hilal bin Mohammed of Sowaik.

The Wali of Mombasa, Salim bin Ahmed, died in March, I835, and his death was the signal for rivalry and dissensions between his brothers, Khamis and Nasir. After more than a year spent in contention the succession was obtained by Salim's son, Rashid.

A deputation from some of the tribes at Mombasa, tired of these wars and quarrels, found Saeed preparing a third expedition, and encouraged by this invitation he hastened his arrangements and sailed from Muscat in November, I836, arriving at Mombasa about the close of the year. He at once summoned Rashid to surrender, but receiving no reply, Saeed landed his troops and batteries on the north side of the creek and commenced a bombardment. Taught by experience, however, of the futility of this method, he founded his hopes upon intrigue, and by lavish expenditure soon gained over a large proportion of those opposed to him, including Khamis and Nasir, the uncles of Rashid. Rashid, seeing the gradual deflection of his adherents, and finding himself unable to hold out against the 
power of Saeed's purse, opened negotiations, and in February, I837. a convention was concluded in the terms of the original pact, by which the fort was to be garrisoned by Saeed's men and the Wali was to reside in the town. Saeed then appointed Ali bin Munsoor to command the fort with a garrison of 500 men, and sailed for Zanzibar. Shortly after, at Saeed's invitation, Rashid paid a visit to Zanzibar, and was then offered the Waliship of Pemba, or a liberal pension, if he would relinquish his title and claim to the Waliship of Mombasa, and quit the place with his family for ever. Rashid declined the proffered baits and maintained his hereditary claim to Mombasa, and Saeed, failing in his attempt to get final possession of the coveted fort by purchase, devised a plan for the extermination of the family of the Mezini chief. Rashid was now honourably treated and sent back to Mombasa with presents, but two months later, Khalid, Saeed's second son, was despatched to that fort with secret orders, which he carried out with great precision and success. On arrival at Mombasa, where he was received with due respect, Khalid landed and held a durbar in Arab fashion at the fort gate. Rashid and the other Mezinis attended the levee, and on making their salutations were desired to enter the fort for the discussion of business. On passing in they were seized one by one and thrown into prison, to the number of thirty. Suspicions then arose, the alarm spread, and the remainder of the Mezinis fled to the mainland. The prisoners were immediately put on board and carried by Khalid to Zanzibar, whence Saeed shipped them to Bundar Abbas in one of his frigates. Some were thrown overboard on the way and the rest were immured and starved to death.

Saeed's wars at Mombasa had been marked throughout by a series of perfidies, and this cruel murder of the gallant Rashid and his companions fittingly completed his conquest. With their death the Mezini Dynasty, which had lasted for over a century, and which neither the Imam Ahmed nor any of his descendants had. been able to overthrow by force of arms, came to an end.

The accession of Her late Majesty Queen Victoria was an opportunity for Saeed to display his loyalty to England, which was not 
neglected by him. In 1838 he despatched Ali bin Nasir as envoy to offer his congratulations with presents of great value, and Captain Cogan, who brought back the mission to Zanzibar, was empowered to negotiate a commercial treaty, which was concluded and signed in May, 1839. Consequent on this treaty Captain Hamerton, of the Bombay army, was appointed Political Agent at Muscat in 1840, and in the following year sailed to Zanzibar, where he took up his residence. He was subsequently instructed to accompany His Highness on his return to Oman.

At this period $(1838)$, it must be noted, Oman was visited by the indefatigable French traveller and botanist, M. Aucher Eloy, who arrived at Muscat in March, and after exploring Jebel Akhdar, returned to that port by the Wady Semail in the following April.

In 1838 the mind of the Indian Government was greatly exercised at the siege of Herat by the Persians, under the instigation of Count Simonovich, the Russian Envoy, and Lord Auckland ordered the Bombay Government to despatch a force to the Persian Gulf to make a counter demonstration. The steam frigate Semiramis, commanded by Captain Brucks, left Bombay with about 400 Sepoys and proceeded to Muscat, from whence, after a short stay, she steamed to Karrack, where she landed the troops under Colonel Sheriff; the steamer Hugh Lindsay subsequently brought reinforcements, and the force was supported by a squadron of ships of the Indian Navy, and the Persians appear to have been somewhat dismayed at the arrival of the British expedition. Orders were at once given for the city walls to be repaired, a work which was carried out with much haste; in September the Shah raised the siege of Herat and the force was then withdrawn.

Sometime in 1839 Saeed received letters from the Governor of Bourbon, who had been moved by representations from French merchants of commercial requirements at Zanzibar, requesting him to receive a French Consul on the same footing as the Americans, and making overtures for a fresh treaty. Saeed, however, demurred to granting an exequatur to the Consul, who had, in fact, already been appointed in anticipation, until the treaty had been concluded. and the appointment was consequently postponed. 
Saeed returned from. East Africa to Oman in September, I839, and had no sooner arrived than he was forced to turn his attention to the adoption of measures for resisting the advance of the Egyptians. Mohammed Ali had at this time embarked on his vain career of aggression in Syria and Arabia, and his General, Khoorshid, had in December despatched Saeed bin Mutlak with a large force and two guns to Beraimi. There was reason to believe that Saeed had been engaged in a secret intrigue with Mohammed Ali for aid in obtaining possession of Bahrain in return for the payment of tribute to Egypt. But under the advice of the British Government Saeed dropped these schemes and evinced proofs of his determination to act loyally in accordance with the policy of the Government in opposing the invasion of the Egyptian troops. In one of his interviews with Mohammed Ali, in April, 1840, Colonel Hodges, the Consul-General at Cairo, desired explanations as to the object of the force under Saeed bin Mutlak ; professions of ignorance and evasions were at iirst resorted to, but the Pasha subsequently admitted that the force was part of Khoorshid's army, and was intended for the annexation of Oman; he was then informed that the British Goyernment would allow no interference on his part with Oman, and would punish any attempt at encroachment. A few months later, the vigorous measures taken by Lord Palmerston and the expulsion of Ibrahim Pasha and his troops from Syria by the combined Enylish and Turkish forces, resulted in Mohammed Ali's evacuation of Arabia in 1840 , whereby Oman was relieved from further danger in that direction.

In I840 Captain Hamerton, who had been nominated as Political Agent at Muscat, was ordered to visit Al-Beraimi from Shargah, to take note of the Wahabee position. In I84I he sailed for Zanzibar, and in the following year received instructions to accompany His Highness Seyyid Saeed when he returned to Oman.

The restless activity of the French in East African waters now greatly troubled the mind of Saeed, and writing to Lord Palmerston from Zanzibar, whither he had again proceeded in 1840 , he did not conceal his fears that that nation had aggressive designs on his 
mainland possession; Saeed's fears were probably not ill-founded. The brig De Messager was dispatched from Bourbon on three occasions to obtain concessions of various kinds, and other indications were not wanting to show that the French were anxious to obtain a footing on the coast, but Saeed had the sense and manliness to resist these demands and to decline to enter into any engagements against his interests. In his complaint, however, concerning the French occupation of Nosse Bé, which belonged, as he averred, to a Sakalava queen, who had put herself under his authority, Saeed was no doubt actuated by jealousy. He had probably not altogether withdrawn his gaze from that quarter and did not look on the French proceedings with equanimity.

Very soon after Saeed had sailed for Zanzibar, his rival, Hamed bin Azzan of Sohar, who, to show his loyalty and amicable feelings towards Saeed, had lately accompanied the latter on a tour of his possessions in the Gulf, seeing in his absence a good opportunity to make another move for the supreme power, set out for Bombay to solicit the neutrality of the Government in the forthcoming struggle. Though accorded a courteous reception in Bombay, the reply he received appears to have effectually discouraged him from further hostilities against Saeed; and soon after his return to Oman he retired from public life and assumed the garb of religion, appointing, at the suggestion of the Lady Moza, his son, Saif, Governor of Sohar, and the since famous priest, Al-Khalelee, Governor of Rostak. Hamed's ascetic habits were utilized by Khalelee io ferment an intrigue among the Batineh tribes, having for its object the election of Hamed as Imam, but it was not generally supported and fell through.

The situation of affairs at Bahrain in $\mathbf{1 8 4 3}$, where civil war had broken out, revived Saeed's long cherished hopes of including that island in his dominions, and Thowaini began to make preparations at Muscat for an expedition. Before embarking on the enterprise, however, Saeed had the prudence to refer to the Indian Government for an expression of their views in the matter, and as it was considered desirable that Saeed should, for fear of bringing on complica- 
tions with the Wahabees and Persians, preserve an attitude of neutrality, the scheme was abandoned by him.

Oman was at this time again threatened by its old enemies the Wahabees. The Ameer Faisal having made terms with Mohammed Ali and returned to Riadh, announced his intention of undertaking the conquest of Oman. Saeed bin Mutlak was despatched to Beraimi with a large force, and a demand was at the same time made upon Thowaini for 25,000 dollars. On receipt of this news the Resident of Bushire advised Thowaini to maintain a friendly understanding with the Wahabees, and to accept any terms compatible with his father's dignity. Thowaini at once requested a truce, desiring time to refer to Zanzibar for orders. Saeed bin Mutlak, however, notwithstanding his compliance with the request, immediately after marched into the Batineh and commenced hostilities. Remonstrances against this action were sent by the Resident to Faisal and to Saeed bin Mutlak, and this intervention, coupled with the fact that the Oman tribes were gathering in formidable numbers to oppose him, induced Saeed bin Mutlak to accept terms, and he eventually withdrew his forces for an annual tribute of 5,000 dollars, the authorization for which Thowaini had received from Zanzibar. The invasion thus terminated in a manner more favourable to Saeed than might have been expected. The increasing indifference to home affairs on Saeed's part was exemplified on this occasion by his not returning to guide his people in their defence against aggression; he was, moreover, exhausting his resources at this time in his campaign against the town of Siwi in East Africa. For this enterprise he had made extensive and costly preparations, and his force of 2,000 men was despatched in March, 1844, under the command of Hamed bin Ahmed al-Samar. It ended in a terrible disaster; the attack was badly planned, and the Arab army was routed and almost annihilated by the natives, who killed many of the leading Shaikhs, including the commander, and captured the whole of the artillery and stores; the remainder of the army fled back to Zanzibar, and His Highness never again attempted to interfere with Siwi, where he had already suffered so many reverses. 
It was in this year that Saeed had the felicity to conclude his third treaty with a great Power. On November 4th, I844, the French Commodore on the East Indian station, Captain Romain Desfossés, arrived at Zanzibar in the Crocodile, with a draft treaty of friendship and commerce. Saeed had previously communicated the proposals of the French Government in this matter to the English Foreign Office, and it was with the approval of the Secretary of State that he consented to negotiate. The treaty was signed on November 17 th, and on the same day the first French Consul, who had been accommodated with a passage in the Crocodile by the Commodore, entered on his functions, although the treaty was not ratified until a year later.

The treaty was followed the next year by the despatch of a French surveying expedition to Madagascar and East African waters, under the command of Captain Guillain, who had visited those waters some years previously in command of the sloop Dordogne. This survey was carried out by him in the brig Ducovedic, I 8 guns, during the years $1846-7$, and his intelligent and zealous labours resulted in the acquisition of much valuable knowledge respecting the Zanzibar coast and its people. One of the chief objects of this enterprise appears to have been the acquisition of a strategical point on the mainland coast, that, like Mayotte, might act as a counterpoise to the new British settlement at Aden, and with this view Captain Guillain, about 1847 , endeavoured to induce the native chiefs of Lamoo and Brava to sell those ports to the French Government. Saeed, however, to whom the ports belonged by conquest, had early news of the intrigue and was able to frustrate it.

It was at this time that Hilal, Saeed's eldest son, proceeded to England to beseech the intercession of Her Majesty's Government with his father, and it may be convenient here to turn aside from political events a little and glance at the relations in which Saeed stood towards his sons. Saeed's family now consisted of twelve, of whom the first was Hilal, who was born in 1815 . He is described as tall, fair and handsome, noted for his courage and revered by the Arabs, who deemed him the most shrewd and energetic of all the rol.. 11. 
sons. He was so much a favourite that he would, it is said, have proved a very formidable rival to his father had he chosen to head a rebellion. The knowledge of this by Saeed had not improbably something to do with the continuance of that deep-rooted dislike and aversion which had been manifested towards Hilal from childhood. The estrangement continued to increase until Hilal's twentysixth year, when his father, having determined to disinherit him, recalled him from Burka, where he had been Wali for some years, to Zanzibar, and never again entrusted him with any position of authority.

In July, I844, Saeed, with the express object of finding out whether he would be upheld in disinheriting Hilal, had written to Lord Aberdeen, saying that it was his wish that Thowaini should succeed him in Oman and Khalid in East Africa. The reply, however, was a diplomatic one, expressing hopes that Saeed would restore Hilal to favour. The supercession of Hilal by his father appointing Khalid to act as Regent at Zanzibar, and Thowaini at Muscat, during his absence from either place, was a cause of many quarrels, as Hilal was always insisting on the governorship of one or other of these capitals as being his by birthright, and indignant at length at what he considered his father's unjust treatment of him, he proceeded to England in September, I845, to represent his condition to Her Majesty's Government. Having kept his father in ignorance of his intentions, Hilal was not afforded an official reception in London, but he seems to have gained much sympathy, and strong letters were written in his favour. Saeed, however, was exasperated by this visit and consequent exposure of his conduct, and though for a time more indulgent outwardly, became really more bitter in his dislike, and in November, I849, Hilal was exiled from Zanzibar for ever. Hilal retired first to Lamoo, and thence moved on to Aden, where he arrived in a destitute condition. He had, however, long been in failing health, and disease accelerated by mental worry soon brought his life to an end. Surrounded by all his family his sad story closed on September 28th, $185 \mathrm{I}$.

The causes of Saeed's hatred of his eldest son are obscure and 
will probably ever remain so. Scandal rumoured that Hilal had violated his father's harem, but the story is doubtful, and it is more probable that the estrangement was due to harem intrigues and to jealousy, as Hilal's mother, an Abyssinian, died when he was an infant, while Khalid's mother was an especial favourite, and would naturally endeavour to prejudice her lord in favour of her own son. Khalid was born in I8I9 of a Malabar concubine, who had great influence over Saeed, and did not scruple to use it ; he was of a mean and penurious disposition, and was much despised by the Arabs as he was petted and indulged by his father. His energies were entirely absorbed in trade, by which he amassed a large fortune, and on account of this he was generally known and spoken of as the "Banian." Saeed was very anxious that Khalid should succeed him, but fate decreed otherwise, and Khalid, after a long illness, died on November 7 th, 1854. Two years younger than Khalid, and born of a Georgean mother, Thowaini was brave and generous, and much respected by the Arabs. He was greatly superior to Khalid, but could never have held his own against Hilal in Oman, and it was for this reason chiefly that the latter was recalled to Zanzibar in r84r. Saeed had much faith and confidence in Thowaini, and had publicly announced that he wished him to succeed as ruler at Muscat.

The next few years of Saeed's life were tolerably uneventful, and were spent in the relaxing climate of Zanzibar, where his sensual habits must have tended to unfit him for the active government of his Arab dominions. During his long residence in East Africa Saeed's main employment was to look after his estates and trading ventures and to continue to add to his already large and unwieldy navy.

Reverting now to affairs in Oman, we see that a treaty for the suppression of the slave trade was concluded by the Resident with Saif bin Hamed, Chief of Sohar, in June, 1849. Saif's position, however, was at this time very precarious, and the treaty never actually came into force. As previously stated, Hamed had some years before become a religious recluse and retired into Rostak voL. II. 
with the intriguing Metowwa Khalelee, leaving Sohar to Saif, who, though nominally independent, was held in check by a number. of fanatical Metowwas or priests. Saif, finding his position intolerable, endeavoured to dispossess these priests, who had gradually usurped his authority, but failing to do so, was himself seized in the fort and, together with his uncle Kais, thrown into prison, where they remained for some time, while the priestly faction exercised full power over the town and district. Escaping from confinement, Saif called in the aid of Khatan bin Saif, Wali of Shinas, and having recaptured Sohar, rooted out the Metowwas and resumed sway over it.

Fully recognizing the power of the intriguing priests, Saif now made friends with Seyyid Thowaini, with a view to strengthening his position against them, but with Khalelee he was dealing with a foe as subtle and vindictive as St. Dunstan. Having obtained the reluctant consent of Hamed, who had long been inextricably in the toils of the religious party, Khalelee procured the assassination of Saif by the hand of one of the attendants, and Hamed was then induced to return to Sohar and resume the government. Partly in connection with the Joasmee designs on Shinas and Khor Fakan and also in obedience to orders from his father at Zanzibar to capture Sohar and seize Hamed, Thowaini despatched a force to the Batineh by land, whilst he himself proceeded thither by sea in the frigate Faiz Allum, in the beginning of 1850. On arrival at Sohar, Thowaini, under the mask of friendship, invited Hamed to renew the former treaty and to discuss plans for joint operations against the Wahabees; several interviews took place, and at one of these near Shinas, Hamed was suddenly seized and carried prisoner to Muscat, in the Faiz Allum, where he was confined for some time in Jelali fort and put to death on April 23rd, 1850, by starvation or poison.

The main purpose of Thowaini, under instructions from his father, had been to gain possession of Sohar, but in this enterprise he was foiled by the energy of Kais bin Azzan, who on the return of Thowaini to Sohar, in May, 1850, at once applied to Shaikh Sultan bin Sakar, the Joasmee, for assistance. Thowaini's siege operations were ineffective, and the combined efforts of Kais and the Joasmees 
at length compelled Thowaini to raise the blockade and return to Muscat. Kais, moreover, succeeded in capturing Shinas, Khor Fakan, and Ghulla, but not content with this, he arrested Khatan bin Saif, who had been concerned in the seizure of Hamed, and cruelly murdered him by decapitation with a blunt sword.

The removal of the restless and ambitious Hamed from the scene was a great relief to H.H. Seyyid Saeed, especially as the religious party, at the head of which Hamed had put himself, was now gathering strength in Oman, and Thowaini received the unqualified approval and support of his father for his conduct of the matter. It was recognized throughout Oman, indeed, that Thowaini had acted in the true spirit of Arab policy, and it was believed, moreover, that the treachery had not been carried out without direct authority from Zanzibar.

On the news of these events reaching India, however, the action of Thowaini was viewed with disapprobation by the Government, his conduct towards Hamed being characterized as a violation of the treaty. Saeed, after much urging, at length realized the necessity of his presence in Oman, where he arrived on May r6th, r85I, and he at once began to prosecute war against Kais bin Azzan and the Joasmees. He moved first against Khaboora, which soon submitted, and then with little difficulty recaptured Shinas. Ultimately, deserted by the Joasmees, Kais made terms and retired to Rostak with a pension of 200 dollars monthly, Sohar being surrendered to Saeed, who thus for the second time became its unquestioned possessor. By his success in this campaign and his subsequent judicious arrangements with the leading Shaikhs and Chiefs of Oman, Saeed greatly increased his reputation, and his authority became more firmly established than it had been for many years previously.

Eager to be relieved from the cares of ruling his contentious people, His Highness set sail from Muscat in November, 1852, but the appearances of tranquillity were deceptive and his departure at this juncture was most inopportune; he had hardly quitted the shores when Thowaini was confronted by an unforeseen and formidable invasion. 
A large Wahabee force under Abdulla, the son of the Ameer Faisal, appeared on the threshold of the country and re-occupied their former base at Beraimi, with the object of finally annexing Oman to the Nejdian Empire. Abdulla bin Faisal began by summoning the principal Chiefs and Shaikhs to his camp, and by demanding from Thowaini the surrender of Sohar and the payment of an exorbitant tribute. Alarmed at these terms, Thowaini moved up to Sohar to prepare for defence against aggression; meanwhile Captain Kemball, the Resident in the Gulf, at the request of Thowaini, proceeded to the Pirate coast in the Company's cruiser, Clive, and by his vigorous remonstrances induced Abdulla bin Faisal to alter his tone and abate his pretensions. An agreement was then come to, by which the Muscat Government was to pay. an annual tribute of 12,000 dollars and arrears to the amount of 6,000 dollars, the Ameer's son binding himself to support Thowaini in all his political difficulties. In these negotiations the Resident had been much assisted by the firm stand made against the Ameer's son by Saood bin Tahnoon, Shaikh of the Beni Yas at Abu Thabee, who had refused to be intimidated by the Wahabees. In the latter part of I85.3 Abdulla bin Faisal returned, to Nejd, leaving Ahmed al-Sideyree in command of the force stationed in Oman territory.

Elated by his success against Kais, Saeed, on quitting his native country in 1852 , had indulged the fond hope that he might be suffered to spend the remainder of his days in peace in the beautiful island he had chosen for his residence. His health and strength, it is said, had given way greatly in the last few years, and it was natural enough at his age and with his enfeebled constitution that he should seek repose. The recent invasion of the Wahabees and the offensive treatment of the Arab Governor of Bundar Abbas by the Persians, forced him to turn once more to Muscat. On April 15th, 1854, His Highness paid a visit to the Residency together with his principal officers, and placing the hand of his son Khalid in that of Colonel Hamerton, expressed a desire that the latter should remain at Zanzibar during his absence, and that he, Hamerton, would guide his son with advice in all doubts and difficulties, especially with 
reference to foreign designs on his dominions, and Colonel Hamerton, having consented to comply with His Highness's wishes, received the homage of the Arabs present, in token of their loyal submission to their ruler's commands. Saeed then embarked on the Victoria frigate on the I8th, and sailed for Muscat, where he arrived some days later.

Two months after Saeed's departure, Captain Fremantle, of H.M.S. Juno, who had been sent on a mission to obtain the cession by purchase of the Kooria Mooria Islands, on which were valuable guano deposits, arrived at Zanzibar. The. French had on several occasions endeavoured to get possession of the guano, but their negotiations had always failed. Captain Fremantle's efforts, however, were more successful. Having proceeded on to Muscat, he had no sooner intimated the desire of the Government to acquire the islands than Saeed, at once refusing the offer of purchase, agreed to their transfer, and made them over by a deed of gift dated July I4th, I854

The hostile proceedings of the Persians at Bundar Abbas, who, under the belief that the town and strip of coast had been farmed to the Arabs on terms much too lenient, had insulted and expelled the old Governor, Saif bin Nebhan, and his garrison, and had resumed possession of the district, had greatly mortified and incensed His Highness, whose first attention was directed to the recovery of his rights. Having without loss of time equipped an expedition, he despatched it under Thowaini to Bundar Abbas, which was soon re-occupied. Fresh troops, however, were marched down from Shiraz, and reinforced by these, the Persian commander again expelled the Arabs, and Saeed, after an ineffectual blockade, was compelled to abandon the hope of recovering his supremacy over the Persian coast by force of arms. Negotiations were then opened, and a convention was eventually concluded in April, 1856, by which the lease was renewed to Saeed by the Shah for twenty years, at an increased rental of $x 6,000$ tomans, under several stringent conditions. which were very derogatory to Saeed's pride. Unfavourable as the terms were, however, Saeed gladly accepted them rather than vol. II. 
relinquish the farm, and he at once re-took charge of Bundar Abbas and appointed a Wali and Customis farmer to resume control over the territory.

One of the first acts of Saeed on his arrival at Muscat had been to appoint his fifth son, Toorkee, as Wali of Sohar, a post which he continued to hold for some years.

At the time of Saeed's departure war had broken out between England and Persia in consequence of the Shah's designs on Herat, which was captured on October 25th. Lord Dalhousie's declaration of war was followed by the despatch of an armament from Bombay in November, 1856 , and the naval commander, Admiral Sir $\mathrm{H}$. Leeke, having embarked in the Company's frigate Assaye, arrived at Muscat in the same month and thence proceeded up the Gulf. Bushire and Mohammerah were soon after taken and occupied, and by the Treaty of Paris in March, 1857, Persia abandoned all claims to Herat and agreed to evacuate that fort.

His Highness Seyyid Saeed, finding his presence no longer urgently required in Oman, only remained there until the change of monsoon enabled him to turn his face southwards, and then, having appointed his son Thowaini his Deputy in Arabia, and taking leave of his aged mother, whom he never expected to see again, he set sail on September ${ }^{5} 5_{\text {th, }}$ in the Victoria frigate, accompanied by the sloop Artemise, with his son Burgash on board. After touching at Soor to transact business, Saeed continued his journey, but on September $\mathrm{r} 8 \mathrm{th}$, was taken ill with swelling of the legs; he continued to grow gradually worse until October 13 th, when dysentery set in, and on Sunday, the I9th, at 8.30 p.m., his life passed quietly away. The Victoria was passing Coctivi Island at the time, and six days after arrived off Chumba Island, in Zanzibar harbour, where she anchored with the Artemise.

The corpse was landed the same night, and in the presence of the sons and Arab notables was interred in the little cemetery near the palace, where a plain horizontal slab of white marble, without inscription, now marks the grave of Oman's famous prince. At the age of 66 years and 7 months, and after a reign of nearly 50 years, 
Saeed thus closed a career which can only be described as remarkable. Left an orphan when a mere youth, his restless and enterprizing spirit urged him to step over a cousin's body to seize with avidity the reins of power, at a time when his country was harassed by foreign invaders and torn by internecine commotion. At such a time an abler and more experienced prince might well have shrunk from accepting the burden, but Saeed apparently felt himself equal to the position, and proved himself to be so.

In character Saeed was a worthy and typical example of the Arab race. He was very courageous, and on many ofcasions displayed exalted personal bravery. He was sagacious and shrewd, courteous and dignified, generous and magnanimous. But he possessed also the antagonistic qualities of the Arab, for he was too often vindictive and cruel, perfidious and covetous. $\mathrm{He}$ was beloved by all his people and was a man after their own heart. Saeed was admittedly unrivalled in the tact and discrimination he exhibited in dealing with the Arab tribes. His Highness can claim the distinction that he was the first Arab prince to effect the pacification of the East Coast of Africa, and that by his encouragement and protection of commerce, he made his capital the emporium of trade between India, Persia, and Arabia, and immensely increased the wealth of his country. Attracted by the equity of Saeed's government and the superior security of Muscat from piratical neighbours. these merchants soon flocked to the port, which thus became an important entrepôt.

The rapid development of East African commerce was due to his fostering care and protection, and the wisdom and foresiglit he displayed in this matter were rewarded by the increase of his revenue, which was mainly derived from Customs dces, which rose from 200,000 dollars, when he first assumed power, to five or six times that amount in his latter days. On nothing did Saeed lavish more money and attention than in acquiring ships and fitting them out as men-of-war. The largest vessel he ever possessed was the Liverpool, a two-decker of 74 guns, launched in I826. which was presented by Saeed to the British Government, by whom it was 
re-named the Imam. In 1847, when his navy was somewhat reduced, it is said to have consisted of nine frigates and corvettes, of which the largest was the Shah Allum, of 54 guns, and half a dozen sloops and brigs.

Saeed's relations with the British Government were from almost the commencement of his career of the most friendly description, and though this was, of course, in part the dictate of policy-for on several occasions his rule only escaped collapse by our interventionyet he was unquestionably well disposed to us at heart ; and the son who has followed closest in his father's steps in this respect, Toorkee, has been heard to say that Saeed repeatedly counselled his children to stand at all times loyally by the British Government, and never to refuse any request that might be made by them. 